
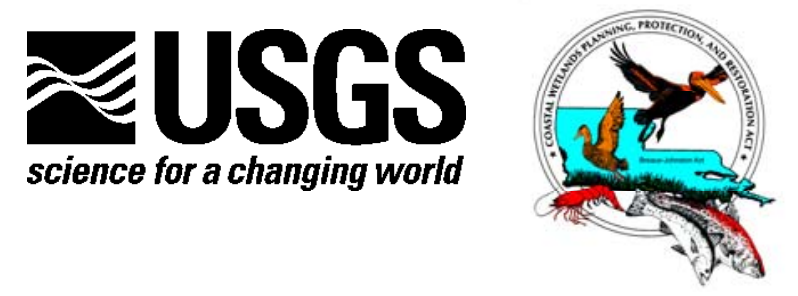

\title{
CRMS Vegetation Analytical Team Framework: Methods for Collection, Development, and Use of Vegetation Response Variables
}

By Kari F. Cretini, Jenneke M. Visser, Ken W. Krauss, and Gregory D. Steyer

Open-File Report 2011-1097

U.S. Department of the Interior

U.S. Geological Survey 


\section{U.S. Department of the Interior \\ KEN SALAZAR, Secretary}

\section{U.S. Geological Survey \\ Marcia K. McNutt, Director}

U.S. Geological Survey, Reston, Virginia 2011

For product and ordering information:

World Wide Web: http://www.usgs.gov/pubprod

Telephone: 1-888-ASK-USGS

For more information on the USGS-the Federal source for science about the Earth, its natural and living resources, natural hazards, and the environment:

World Wide Web: http://www.usgs.gov

Telephone: 1-888-ASK-USGS

Suggested citation:

Cretini, K.F., Visser, J.M., Krauss, K.W.,and Steyer, G.D., 2011, CRMS vegetation analytical team framework-Methods for collection, development, and use of vegetation response variables: U.S. Geological Survey Open-File Report 2011-1097, 60 p.

Any use of trade, product, or firm names is for descriptive purposes only and does not imply endorsement by the U.S. Government.

Although this report is in the public domain, permission must be secured from the individual copyright owners to reproduce any copyrighted material contained within this report. 


\section{Contents}

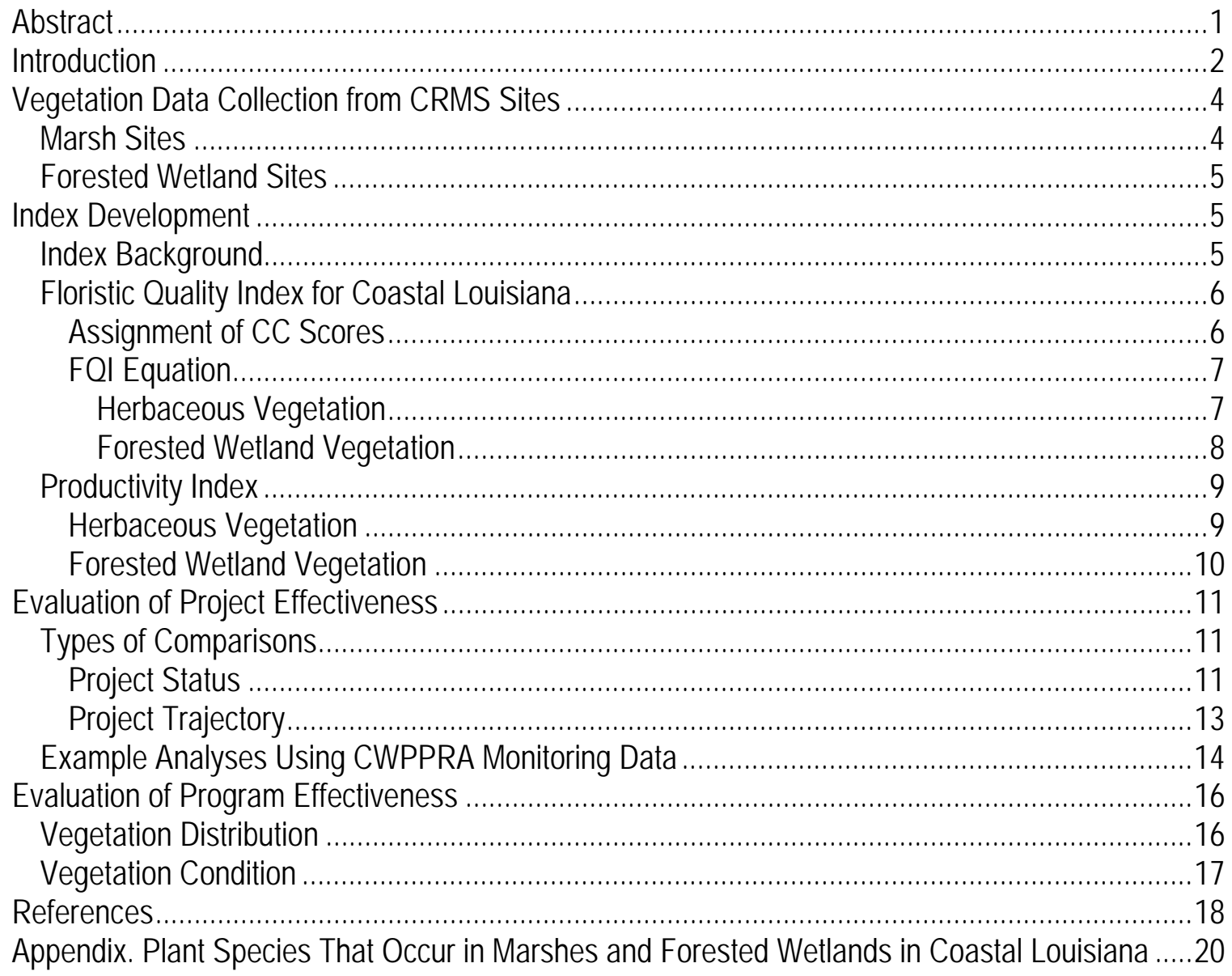

\section{Figures}

Figure 1. Louisiana coastal area with Coastwide Reference Monitoring System (CRMS) sites and Coastal Wetlands Planning, Protection and Restoration Act (CWPPRA) project areas depicted. CRMS sites are displayed according to the 2008 marsh type.

Figure 2. Conceptual model of environmental drivers of vegetation performance....................... 4

Figure 3. Relationship between site salinity and mean basal area increment $\left(\mathrm{cm}^{2} / \mathrm{yr}\right)$ of Taxodium distichum codominant trees in Louisiana (open circle) and South Carolina (closed circle) swamps. The 75 percent quantile was the largest significant quantile $(\alpha=0.10)$ (data after Krauss and others, 2009).

Figure 4. Example of graphing Coastwide Reference Monitoring System information used to evaluate a project's condition. The dashed line indicates the index score (0-100) for the project being evaluated. Data used to generate these graphs will include only data from those CRMS sites that are within the same wetland type and geological setting..

Figure 5. Example of graphing Coastwide Reference Monitoring System (CRMS) information used to evaluate a project trend. Graphs will be generated with data from CRMS stations that have the same marsh types and geological settings as those of the project data. 
Figure 6. Mean $( \pm \mathrm{SE})$ floristic quality index scores for CS-20 project and reference stations by year. Green shaded area indicates ideal range for brackish marshes in the chenier plain.

Figure 7. Mean ( \pm SE) productivity index scores for CS-20 project and reference stations by

year. Green shaded area indicates ideal range for brackish marshes in the chenier plain. . .16

\section{Tables}

Table 1. Overview of vegetation response variables and applicable wetland type for Coastwide Reference Monitoring System assessment.

Table 2. Vegetative cover values for the Braun-Blanquet method (reproduced from Folse and others, 2008).

Table 3. Assignment of coefficient of conservatism (CC) scores to different plant species for coastal Louisiana (modified from Cohen and others, 2004).

Table 4. Louisiana coastal vegetation expert panel.

Table 5. Ideal range for vegetation indices based on the vegetation anlaysis team's best professional judgment. As more field data are collected through the Coastwide Reference Monitoring System and other research projects, these ranges may need to be adjusted to reflect the best available data.

Appendix Table.\# Plant species that occur in marshes and forested wetlands in coastal Louisiana.

\section{Conversion Factors}

\begin{tabular}{lcl}
\hline \multicolumn{1}{c}{ Multiply } & By & \multicolumn{1}{c}{ To obtain } \\
\hline centimeter $(\mathrm{cm})$ & 0.3937 & inch (in.) \\
meter (m) & 3.281 & foot (ft) \\
meter (m) & 1.094 & yard (yd) \\
\hline & Area & \\
\hline square meter $\left(\mathrm{m}^{2}\right)$ & 0.0002471 & acre \\
hectare (ha) & 2.471 & acre \\
square centimeter $\left(\mathrm{cm}^{2}\right)$ & 0.001076 & square foot $\left(\mathrm{ft}^{2}\right)$ \\
square meter $\left(\mathrm{m}^{2}\right)$ & 10.76 & square foot $\left(\mathrm{ft}^{2}\right)$ \\
square centimeter $\left(\mathrm{cm}^{2}\right)$ & 0.1550 & square inch $\left(\mathrm{ft}^{2}\right)$ \\
hectare (ha) & 0.003861 & square mile $\left(\mathrm{mi}^{2}\right)$
\end{tabular}




\title{
CRMS Vegetation Analytical Team Framework: Methods for Collection, Development, and Use of Vegetation Response Variables
}

By Kari F. Cretini, ${ }^{1}$ Jenneke M. Visser, ${ }^{2}$ Ken W. Krauss,${ }^{1}$ and Gregory D. Steyer ${ }^{1}$

\begin{abstract}
This document identifies the main objectives of the Coastwide Reference Monitoring System (CRMS) vegetation analytical team, which are to provide (1) collection and development methods for vegetation response variables and (2) the ways in which these response variables will be used to evaluate restoration project effectiveness. The vegetation parameters (that is, response variables) collected in CRMS and other coastal restoration projects funded under the Coastal Wetlands Planning, Protection and Restoration Act (CWPPRA) are identified, and the field collection methods for these parameters are summarized. Existing knowledge on community and plant responses to changes in environmental drivers (for example, flooding and salinity) from published literature and from the CRMS and CWPPRA monitoring dataset are used to develop a suite of indices to assess wetland condition in coastal Louisiana. Two indices, the floristic quality index (FQI) and a productivity index, are described for herbaceous and forested vegetation. The FQI for herbaceous vegetation is tested with a long-term dataset from a CWPPRA marsh creation project. Example graphics for this index are provided and discussed. The other indices, an FQI for forest vegetation (that is, trees and shrubs) and productivity indices for herbaceous and forest vegetation, are proposed but not tested. New response variables may be added or current response variables removed as data become available and as our understanding of restoration success indicators develops.

Once indices are fully developed, each will be used by the vegetation analytical team to assess and evaluate CRMS/CWPPRA project and program effectiveness. The vegetation analytical teams plan to summarize their results in the form of written reports and/or graphics and present these items to CRMS Federal and State sponsors, restoration project managers, landowners, and other data users for their input.
\end{abstract}

\footnotetext{
${ }^{1}$ U.S. Geological Survey

${ }^{2}$ University of Louisiana at Lafayette, Department of Renewable Resources and Institute for Coastal Ecology and Engineering, Lafayette, La.
} 


\section{Introduction}

In 2003 the Coastwide Reference Monitoring System (CRMS), a network of 392 monitoring sites along the coast of Louisiana, was implemented under the Coastal Wetlands Planning, Protection and Restoration Act (CWPPRA; Steyer and others, 2003, 2006). The CRMS monitoring sites characterize the Louisiana coastal wetland landscape as they are located within all marsh types (fig. 1). The CRMS network also represents the coastal Louisiana restoration project area as sites are located inside and outside of other CWPPRA projects (fig. 1). Sites located outside projects are used as references for project effectiveness to be assessed against. Comparisons at other spatial scales including marsh type and hydrologic basin are also possible through CRMS (Steyer and others, 2003, 2006).

To assess performance of restoration projects associated with CRMS it is important that we use existing knowledge to establish appropriate restoration targets (that is, goals). The existing knowledge includes descriptions of community and plant responses from published literature and the extensive dataset maintained by the CRMS analysis teams and their collaborators. These sources can help us define how a wetland community type is expected to respond to natural variations in major environmental drivers and help us develop a suite of indices to assess wetland condition. Individual indices for vegetation, hydrology and soils will be developed to assess the condition of these parameters at a CWPPRA project or group of projects. The indices along with other community response variables can be used to assess restoration project effectiveness.

In this document, we focus on emergent vegetation. Emergent vegetation, sampled within CRMS marsh and forested wetland sites, provides a description of the community types of coastal Louisiana over time (Folse and others, 2008). Several vegetation response (that is, performance) variables (table 1) are used to document subtle changes in vegetation assemblage associated with either natural degradation or restoration projects. A current conceptual model (fig. 2) of the environmental drivers of plant performance identifies flooding, salinity, and nutrient availability as the key components in coastal Louisiana ecology. The first two environmental drivers, flooding and salinity, are monitored through CRMS. The prevailing idea among project managers is that restoration projects can affect flooding and salinity by (1) altering the amount of water exchange between the project and surrounding area and/or (2) changing the project area elevation through sedimentation, nutrient gains, or nutrient deficits. Although nutrient availability is not currently monitored, it may have nutrient feedbacks that can indirectly alter wetland elevation gain (fig. 2; McKee and others, 2007).

The purpose of this document is to provide to those associated with CRMS (that is, Federal and State sponsors, project managers, landowners, data users etc.) with the following: (1) the collection and development methods for the vegetation response variables and (2) the ways in which these response variables will be used to evaluate CRMS project and program effectiveness. New response variables may be added, or current response variables may be removed, as data become available and as our understanding of restoration success indicators develops. 


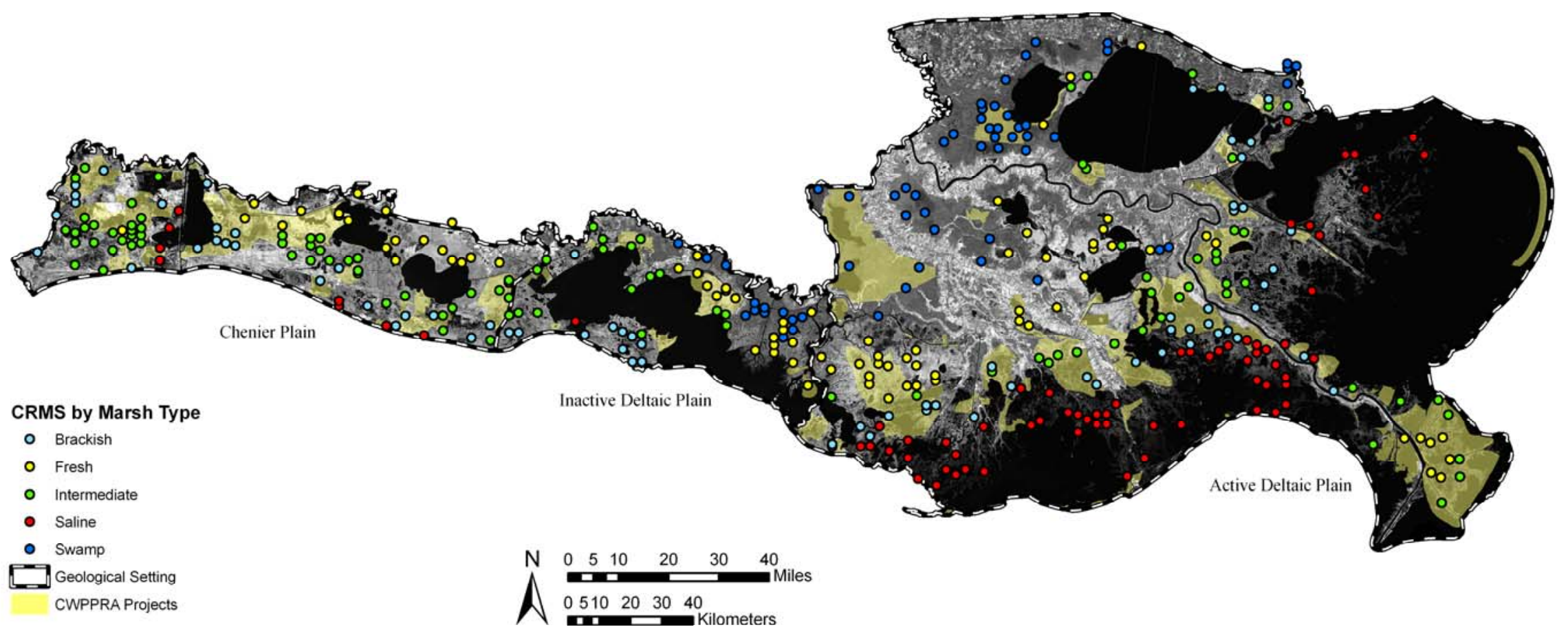

Figure 1 Louisiana coastal area with Coastvide Reference Monitoring System (CRMS) sites and Coastal Wetlands Planning, Protection and Restoration Act (CMPPRA) project areas depicted. CRMS sites are displayed according to the 2008 marsh type. 
Table 1. Overview of vegetation response variables and applicable wetland type for Coastwide Reference Monitoring System assessment.

\begin{tabular}{ll} 
Vegetation response variables & Marsh or forested wetland \\
\hline Percent total cover of herbaceous vegetation & Both \\
Height of dominant herbaceous vegetation & Both \\
Floristic quality index (FQI) & Both \\
Productivity index & Both \\
Diameter at breast height (DBH) & Forested wetland \\
Basal area & Forested wetland \\
Basal area increment (BAI) & Forested wetland \\
\hline
\end{tabular}

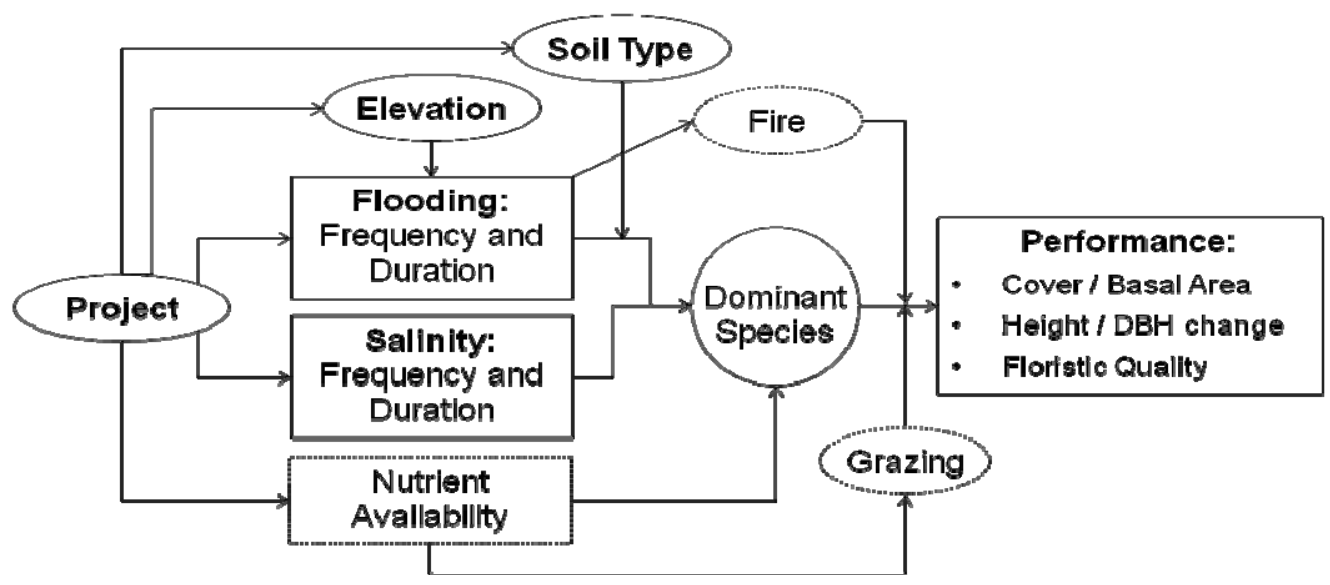

Figure 2. Conceptual model of environmental drivers of vegetation performance.

\section{Vegetation Data Collection from CRMS Sites}

A complete description of the methods and sampling design for collecting vegetation data in emergent marsh and forested wetlands can be found in Folse and others (2008). Summaries of these methods and designs for emergent marsh and forested wetland sites are given below.

\section{Marsh Sites}

Sampling is conducted within ten $2 \mathrm{~m} \times 2$-m vegetation stations along a $282.8-\mathrm{m}$ transect within each $200 \mathrm{~m} \times 200$-m CRMS site (Folse and others, 2008). The same stations are sampled on repeat visits unless the station is lost or destroyed by a natural or human disturbance. Within each vegetation station the cover of each plant species is visually estimated near the end of the growing season (August 1 to September 30) by following the Braun-Blanquet cover scale (table 2). Total vegetation cover of each station and cover of each layer (that is, tree, shrub, herbaceous, carpet) is estimated between 0 and 100 percent (Folse and others, 2008). The sum of each vegetation layer 
may exceed 100 percent because of overlapping canopies. The average height of the dominant (that is, greatest percent cover) species is measured in each vegetation station. Plant species nomenclature follows the U.S. Department of Agriculture's (USDA) PLANTS Database (USDA, NRCS, 2008).

Table 2. Vegetative cover values for the Braun-Blanquet method (reproduced from Folse and others, 2008).

\begin{tabular}{ll} 
Cover range (\%) & Braun-Blanquet \\
\hline Solitary & $\mathrm{R}$ \\
$<1$ & + \\
$1-5$ & 1 \\
$6-25$ & 2 \\
$26-50$ & 3 \\
$51-75$ & 4 \\
$76-100$ & 5 \\
\hline
\end{tabular}

\section{Forested Wetland Sites}

Sampling within forested wetland sites is conducted within three $20 \mathrm{~m} \times 20$-m forest stations along a 282.8-m transect within each $200 \mathrm{~m} \times 200-\mathrm{m}$ CRMS site (Folse and others, 2008). Within each station the herbaceous, understory, and canopy layers are sampled during the fall (August 1 to October 31) by using a nested sampling design (Folse and others, 2008). In each forest station there are three $6 \mathrm{~m} \times 6$-m understory stations, each of which contains one $2 \mathrm{~m} \times 2$-m herbaceous station. Canopy and understory layers are sampled every 3 years while herbaceous species layers are sampled each year. Vegetation sampling within the nine herbaceous stations is identical to the sampling procedure within marsh sites (see previous section). For understory layers, the number and height of all woody shrubs and trees $<5 \mathrm{~cm}$ diameter at breast height (DBH) within each of the nine understory stations are recorded. For canopy layers, tree species $>5 \mathrm{~cm} \mathrm{DBH}$ are identified and the $\mathrm{DBH}$ (137 cm above the forest floor) is measured within each of the three canopy (that is, forest) stations. Canopy cover is also collected with a spherical densiometer by averaging cover in the four cardinal directions at the center of each CRMS plot. Hemispherical photography will also be used beginning in spring 2009 to provide data on percent cover and structure of overstory vegetation.

\section{Index Development}

\section{Index Background}

The Floristic Quality Index (FQI) was first developed by Swink and Wilhelm (1979) as a way to quantitatively measure habitat condition based on plant species composition. The FQI is based on a coefficient of conservatism (CC), a score from 0 to 10 that is applied to each plant species in a local flora by local plant experts. Species are scored according to their tolerance to disturbance and conservatism to a particular habitat type relative to all other plant species in the area of geographical interest. Species that are not found in specific habitat types or that are common in disturbed areas (for example, Amaranthus australis) are given low CC scores, while habitat-specific species 
(for example, Spartina alterniflora) are given high CC scores. The FQI is then calculated by using the following equation:

$$
F Q I=\left(\frac{\sum\left(C C_{\boldsymbol{i}}\right)}{\sqrt{N}}\right)
$$

where CCi is the coefficient of conservatism for species $\mathrm{i}$, and $\mathrm{N}$ is the total number of native species at the area of interest.

The FQI has been developed for several regions (Ohio: Andreas and Lichvar, 1995; Andreas and others, 2004; Florida: Cohen and others, 2004; Mississippi: Herman 2005; Wisconsin and Michigan: Bourdaghs and others, 2006). It has been modified to include nonnative species (Andreas and others, 2004; Cohen and others, 2004) and measures of abundance (Poling and others, 2003). The FQI has also been used to determine the level of disturbance in a wetland site, based on the presence of invasive and disturbance-prone species and species indicative of highly disturbed sites (Lopez and Fennessy, 2002; Ervin and others, 2006; Miller and Wardrop, 2006). An FQI for coastal Louisiana was developed to track even subtle changes in Louisiana wetland condition.

\section{Floristic Quality Index for Coastal Louisiana}

\section{Assignment of CC Scores}

We provided a list of 809 plant species occurring in Louisiana coastal wetlands and a list of CC score descriptions for coastal Louisiana (table 3) to 40 Louisiana coastal vegetation experts. These experts were asked to assign CC scores to species across community types (Andreas and Lichvar, 1995) by using the descriptions in table 3. Twenty-four responses were received. A panel of seven individuals (table 4), consisting of authors of this report and experts from the larger group, met to review the responses and establish a final score by concensus. For most species, the median of the response scores was selected as the final score. For some species, the panel felt that the median of the response scores did not adequately reflect the disturbance tolerance and/or conservatism of the species. The panel discussed and revised the score according to their experience with the species in coastal Louisiana (see appendix table for all CC scores).

Although a deviation of the standard assignment method (Andreas and Lichvar, 1995), one species, Distichlis spicata, was assigned community-specific CC scores.

Since this species is a codominant in healthy brackish and salt marshes, it was assigned a high CC score in those habitats. It is indicative of a disturbance, however, when it occurs in fresh and intermediate marshes, so it receives a low CC score in those communities. Scores for each habitat type are available in the appendix table.

The panel did not assign CC scores to (1) submerged aquatic vegetation, (2) parasitic species, (3) plants that were identified only to genus or family, or (4) unidentifiable plants (unknowns). For those plants identified only to genus, we assigned the species value to the genus if that genus had only one species on the list. If more than one species for the genus was listed and those species CC scores were within a 3-point 
range, the mode of the species scores was assigned to the genus. If the CC scores for the species within the genus had a wider range than 3 points, no CC score was assigned.

The panel decided that nonnative species (USDA, NRCS, 2008) would automatically be assigned a zero CC score and would be included in the FQI calculation as these species are indicators of anthropogenic disturbance (Cohen and others, 2004; Allain and others, 2006; Bourdaghs and others, 2006) or some other stress on the site.

Table 3. Assignment of coefficient of conservatism (CC) scores to different plant species for coastal Louisiana (modified from Cohen and others, 2004).

\begin{tabular}{ll} 
CC score & Louisiana description \\
\hline 0 & Invasive plant species \\
$1-3$ & Plants that are opportunistic users of disturbed sites \\
$4-6$ & Plants that occur primarily in less vigorous coastal wetland communities \\
$7-8$ & Plants that are common in vigorous coastal wetland communities \\
$9-10$ & Plants that are dominants in vigorous coastal wetland communities \\
\hline
\end{tabular}

Table 4. Louisiana coastal vegetation expert panel.

\begin{tabular}{ll} 
Name & Affiliation \\
\hline Larry K. Allain & U.S. Geological Survey \\
Ken W. Krauss & U.S. Geological Survey \\
Mike Materne & Louisiana State University \\
Charles E. Sasser & Louisiana State University \\
Gary P. Shaffer & Southeastern Louisiana University \\
Gregory D. Steyer & U.S. Geological Survey \\
Jenneke M. Visser & University of Louisiana at Lafayette \\
\hline
\end{tabular}

\section{FQI Equation}

The FQI equation developed by Swink and Wilhelm (1979) was modified for coastal Louisiana wetlands by (1) including nonnative species, (2) including measures of abundance, and (3) scaling the score from 0 to 100. Separate indices were developed for herbaceous marshes and forested wetlands and are described in the next section. The herbaceous and forested FQIs will be calculated annually for all CRMS and CWPPRA stations with available data. We began using the herbaceous marsh FQI in 2008. It has been calculated by vegetation station for each year where the data are available. The forested wetland FQI will be calculated by station for all years with available data starting in 2009.

Herbaceous Vegetation

Marsh sites throughout the CRMS network are predominately herbaceous although forested wetland vegetation can colonize marsh sites coincident with change. 
For the herbaceous vegetation on all CRMS sites, the FQI is calculated first at the vegetation station level by using one of the two following equations.

If the sum of species cover at a CRMS vegetation station at time $t$ is less than or equal to 100, we use the following formula:

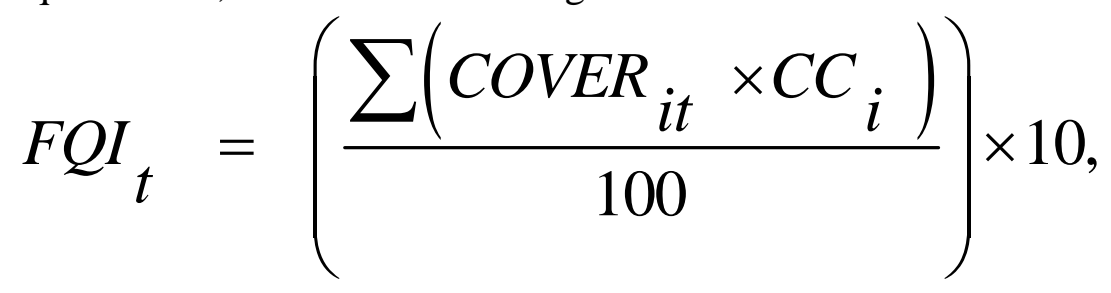

where COVERit is the percent cover for species $i$ at a vegetation station within a CRMS site at time $t$, and $\mathrm{CCi}$ is coefficient of conservatism for species $\mathrm{i}$. This equation allows for a low FQI when the species composition of the site consists of species found in vigorous wetlands (high CC score), but the biomass (as estimated through cover) is low because of environmental stressors.

Where the sum of species cover at a CRMS vegetation station at time $t$ is greater than 100 (overlapping canopies), we use the following formula:

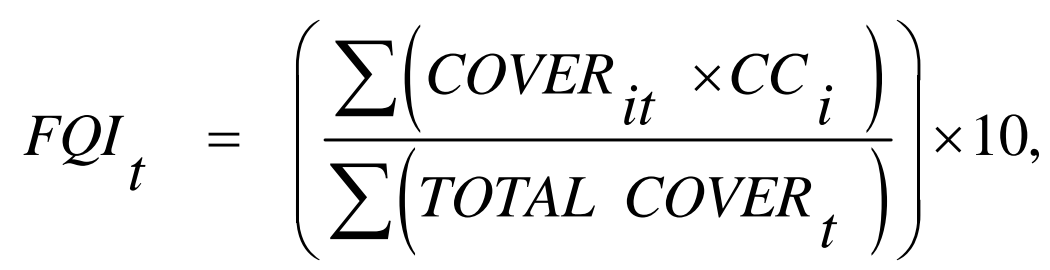

where TOTAL COVER $\mathrm{t}_{\mathrm{t}}$ refers to the cumulative species cover of the vegetation station (that is, > 100\%).

FQI scores for individual stations are averaged to obtain the site-level FQI score and reported with \pm 1 standard error of the mean (SE). Collectively, these two formulas are robust to all types of herbaceous plot data.

Forested Wetland Vegetation

CRMS sites in forested wetlands have at least three canopy layers to be considered: (1) herbaceous layer, (2) understory layer, and (3) canopy layer. Data from herbaceous vegetation stations associated with CRMS forested wetland sites will be treated identically to marsh sites. Consistency with sampling of the herbaceous layer will be critical for comparisons with marsh data. Understory data will not be available until after the 2009 sampling period and so will not be discussed here. The herbaceous and canopy layers will be sampled in 2009 and are important in representing different resolutions for temporal change. We suspect that the herbaceous community will be the first to change in response to environmental change; however, there will be a number of instances where both layers will need to be considered together. For example, pristine forested wetlands with floating aquatic vegetation in the understory (that is, $\mathrm{CCi}=0$ ) will have very low FQI ratings because of the herbaceous layer, but these same sites will have very high FQI ratings for the canopy, reflecting a target condition of restoration. 
For canopy FQI determinations, we will use one of the two following equations. The $80 \mathrm{~m}^{2} /$ ha basal area is the total basal area that occurs in a healthy swamp based on the authors' research experience. Where the sum of basal areas of species at a station within a CRMS site at time $t$ is less than or equal to $80 \mathrm{~m}^{2} /$ ha, we will use the following formula:

$$
F Q I_{t}=\left(\frac{\sum\left(B A S A L A^{2} E A_{i t} \times C C_{i}\right)}{80}\right) \times 10
$$

where BASAL AREAit is the average basal area for species $i$ at a vegetation station within a CRMS site at time $t$, and CCi is coefficient of conservatism for species $i$. This formula allows for swamps with sparse trees with high CC scores (for example, Taxodium distichum) to receive a lower score.

Where the sum of basal areas of species at a station within a CRMS site at time $t$ is greater than $80 \mathrm{~m}^{2} / \mathrm{ha}$, we will use the following formula:

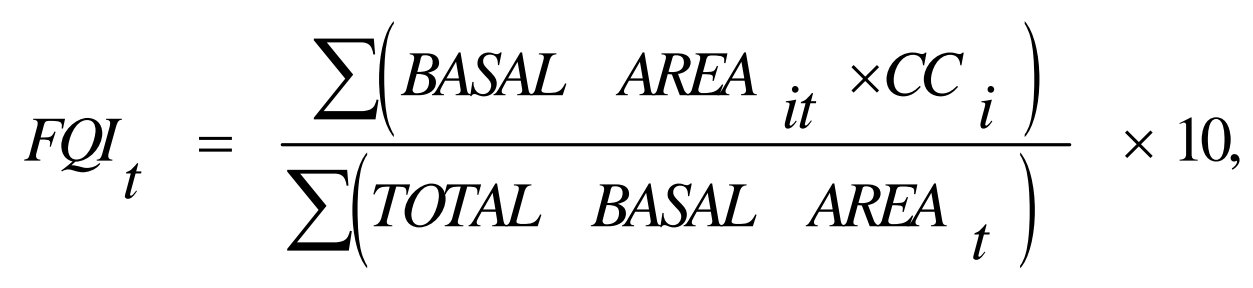

where TOTAL BASAL AREAt represents the total inventory of trees in the same size class for a particular site at time t.

FQI scores for individual stations will be averaged to obtain the site-level FQI score and will be reported with \pm 1 standard error of the mean (SE).

\section{Productivity Index}

Since aboveground biomass collection is not included in the CRMS sampling plan, we will estimate primary productivity in emergent marsh and forested wetlands by using a productivity index. In emergent marsh and forested wetland understory, the productivity index estimates primary productivity by multiplying the height of the dominant plant species by the total vegetation cover. For forested wetland canopy, the productivity index estimates productivity by using basal area increment (BAI) of standing trees. Basal area increment is the difference in basal area of individual trees between sampling times (for example, annually).

\section{Herbaceous Vegetation}

Nondestructive techniques have been used in wetlands to produce estimates of aboveground primary production similar to estimates produced from harvesting 
(Hopkinson and others, 1980; Daoust and Childers, 1998). These techniques require measurements of phenometric variables and an estimation of the stem density. Through CRMS, the average height of the dominant species in each vegetation station is measured, and the total vegetation cover of the station is estimated. Multiplying height and cover gives an estimate of the volume of biomass at each station. Although not as intensive as measurements made in other studies, these data should provide an index of primary productivity that can be compared among CRMS sites. More intensive study of the relationship between this proposed productivity index and actual primary productivity is needed to validate this index.

\section{Forested Wetland Vegetation}

The productivity of forested wetland sites will be dominated by woody vegetation unless sites become so degraded that they convert to marsh. Hence, primary productivity of the understory layer will be assessed similarly to protocols established for herbaceous vegetation in marsh sites. Data from canopy species will be treated separately, however, with productivity being linked to measurements of basal area increment. At a CRMS site, BAI will be calculated for individual canopy stations $(\mathrm{N}=3)$ and summed for the site. While basal area increment does not assess all aspects of forested wetland integrity and productivity (for comparison, see Megonigal and others, 1997), these data will provide reasonable estimates.

An example of basal-area-rated productivity versus an environmental driver within forested wetlands is provided in figure 3. In this example, Krauss and others (2009) calculated BAI for individual trees that were codominants of Taxodium distichum in Louisiana and South Carolina swamps. The BAI data were compared among multiple sites with different salinity regimes and were subjected to quantile regression to indicate different possible responses to salinity. Because habitats differ widely in their response to prolonged levels of stress, such as salinity and flooding, defining critical thresholds depends on whether vegetation in a particular habitat can, under any circumstances, grow adequately. In this example, the annual BAI of codominant trees was natural-logtransformed and was regressed against salinity, with the 5, 10, 25, 50, 75, 90, and 95percent regression quantiles being depicted as lines along the ordinate. While the typical mean regression response is depicted by the 50 percent quantile, in figure 3 it becomes evident that by using basal area increment data that the 75 percent quantile is a better predictor (at $\alpha=0.10$ ) for coastal forested wetland growth increment than is the 50 percent regression quantile. These analyses will be conducted with CRMS data the forested data to determine salinity and flooding duration/frequency thresholds necessary to achieve optimal productivity. 


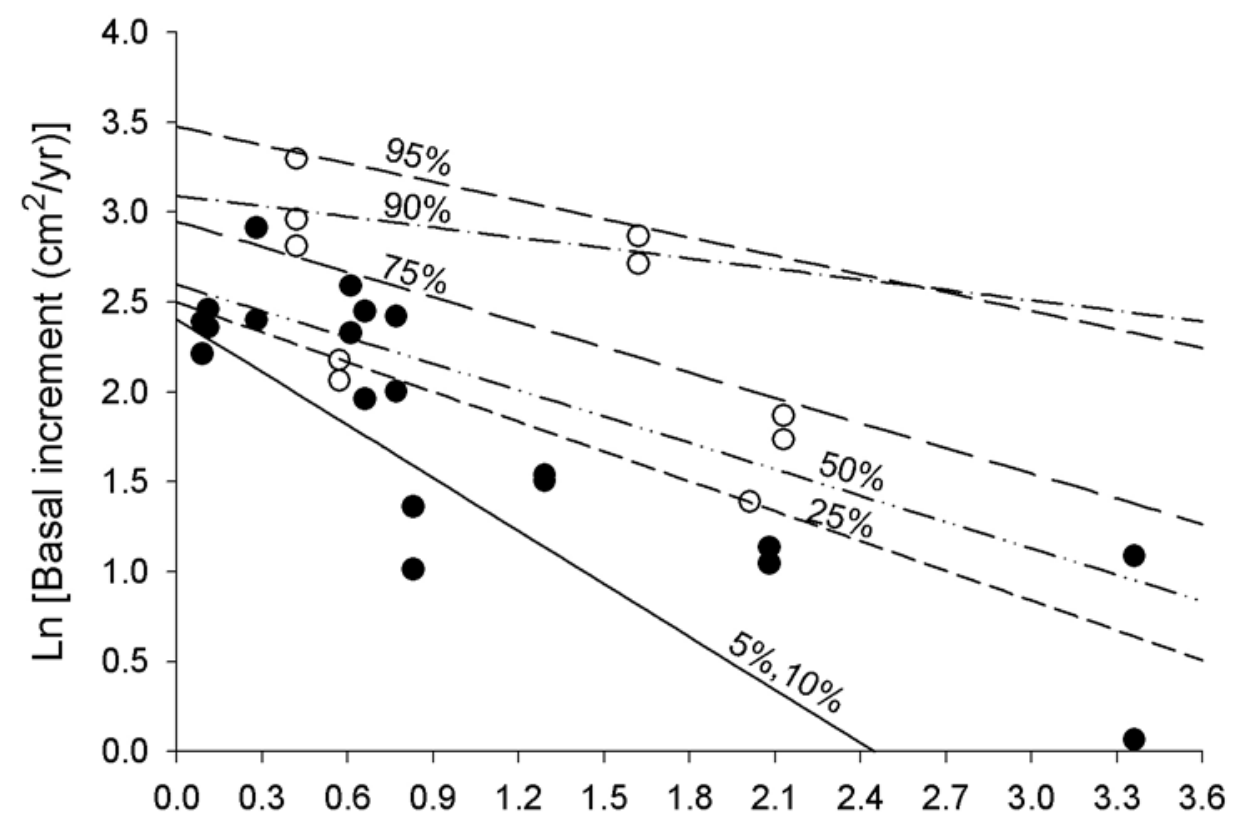

Salinity (ppt)

Figure 3. Relationship between site salinity and mean basal area increment $\left(\mathrm{cm}^{2} / \mathrm{yr}\right)$ of Taxodium distichum codominant trees in Louisiana (open circle) and South Carolina (closed circle) swamps. The 75 percent quantile was the largest significant quantile $(\alpha=0.10)$ (data after Krauss and others, 2009).

\section{Evaluation of Project Effectiveness}

\section{Types of Comparisons}

\section{Project Status}

With only 1 year of data, the status of a project relative to other projects and reference sites can be evaluated. Project status evaluation will consist of comparing the indices derived from the CRMS site(s) within a project to the distribution of the indices from the reference stations, other project stations, and to an ideal (target) range (fig. 4, table 5). Evaluation of project status will occur within the dominant habitat (swamp forest, fresh marsh, intermediate marsh, brackish marsh, or saline marsh; fig. 1) of the project within geological setting (active deltaic plain, inactive deltaic plain, or chenier plain; fig. 1) combination. The evaluation will take into consideration the time since project completion. Condition of project sites is expected to start lower on average than that of reference sites, as restoration projects generally addresses the areas with highest need. 
Since we developed the vegetation indices for coastal Louisiana wetlands to evaluate restoration projects in coastal Louisiana, we determined the ideal ranges using our best professional judgment. The ranges were based on the index scores calculated for coastal Louisiana marshes with available CWPPRA and CRMS data (table 5). Marshes in the active deltaic region, for example, are in a state of primary succession and thus contain a larger number of disturbance species (that is, lower CC score) and as a result they have a lower FQI score compared to marshes in other coastal regions. The ideal ranges in these marshes are thus lower because of the plant species that are found there. Ideal ranges may need to be adaptively adjusted as more information from CRMS sites becomes available.

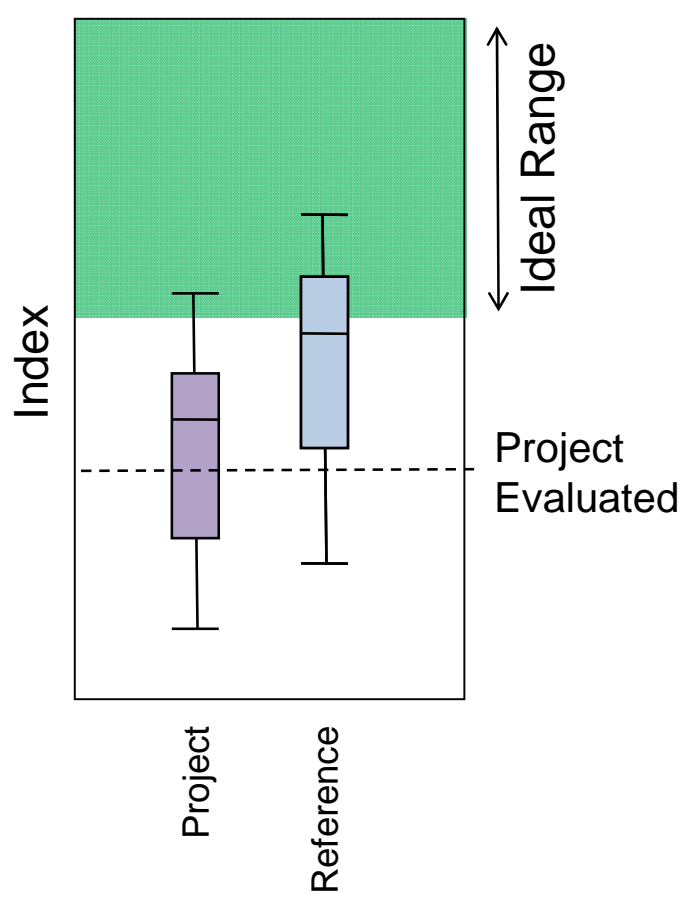

Figure 4. Example of graphing Coastwide Reference Monitoring System information used to evaluate a project's condition. The dashed line indicates the index score (0-100) for the project being evaluated. Data used to generate these graphs will include only data from those CRMS sites that are within the same wetland type and geological setting. 
Table 5. Ideal range for vegetation indices based on the vegetation anlaysis team's best professional judgment. As more field data are collected through the Coastwide Reference Monitoring System and other research projects, these ranges may need to be adjusted to reflect the best available data.

[FQI, floristic quality index]

\begin{tabular}{llll}
\hline & Habitat type & FQI & Productivity index \\
\hline Geological setting & Swamp forest-herbaceous & $>80$ & $>60$ \\
& Swamp forest-canopy & $>80$ & $>60$ \\
& Fresh marsh & $>80$ & $>60$ \\
& Intermediate marsh & $>80$ & $>55$ \\
& Brackish marsh & $>80$ & $>50$ \\
\multirow{5}{*}{ Active deltaic plain plain } & Saline marsh & $>80$ & $>40$ \\
& Fresh marsh & $>70$ & $>55$ \\
Chenier plain & Intermediate marsh & $>70$ & $>80$ \\
& Fresh marsh & $>80$ & $>60$ \\
& Intermediate marsh & $>80$ & $>55$ \\
& Brackish marsh & $>80$ & $>50$ \\
& Saline marsh & $>80$ & $>20$ \\
\hline
\end{tabular}

\section{Project Trajectory}

As more years of data become available, trends in the indices will be compared among project and reference sites (fig. 5). Regression techniques will be used to test for the significant difference in slopes of fitted linear regressions. Each project will be compared to the trends in the reference sites and all other project sites within its habitat and geological setting. 


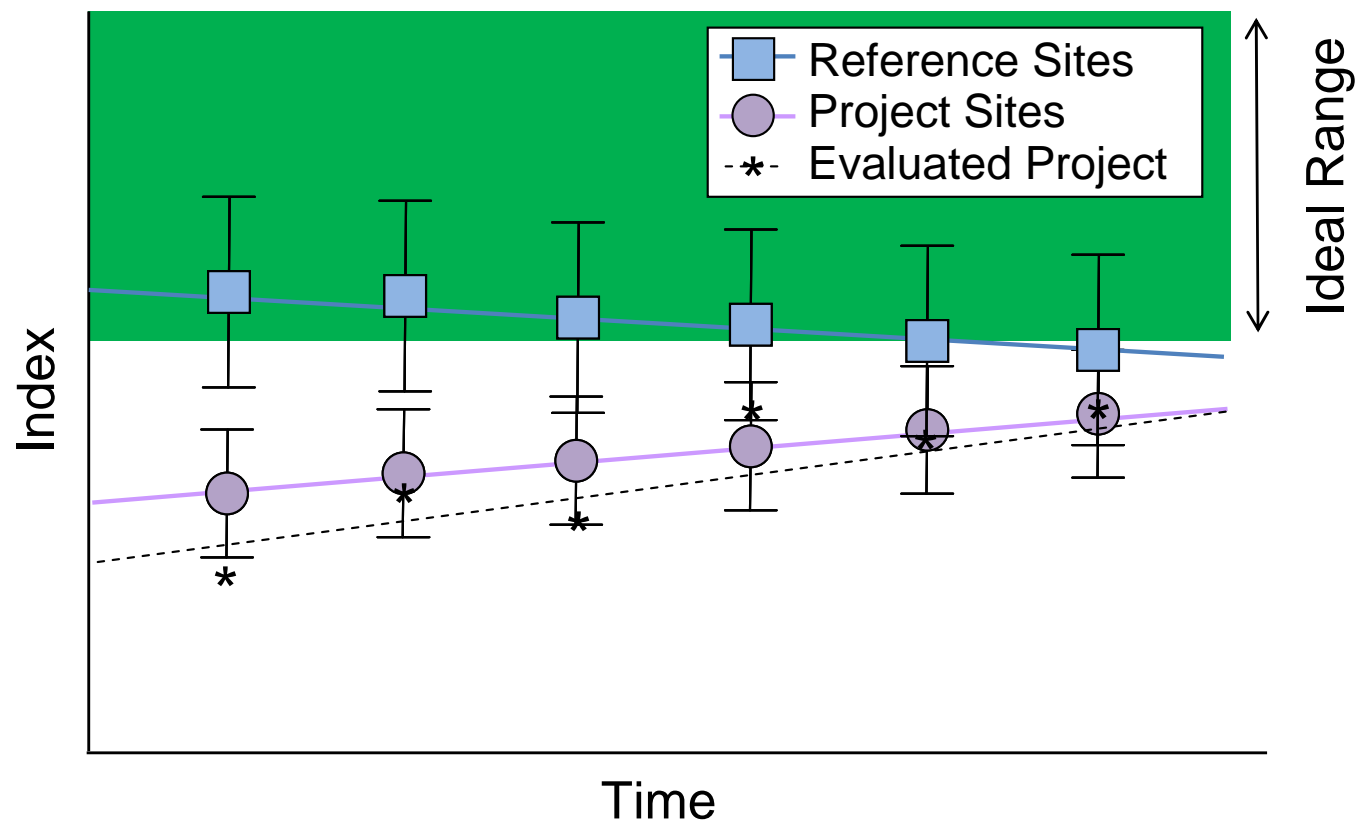

Figure 5. Example of graphing Coastwide Reference Monitoring System (CRMS) information used to evaluate a project trend. Graphs will be generated with data from CRMS stations that have the same marsh types and geological settings as those of the project data.

\section{Example Analyses Using CWPPRA Monitoring Data}

Twelve years of vegetation cover and composition data from the East Mud Lake Marsh Management (CS-20) CWPPRA project were utilized to demonstrate the floristic quality (herbaceous) and productivity indices usage across time and between project and reference sites. An FQI was calculated for each vegetation station by using equations 2 and 3. Vegetation station FQI scores were averaged by station type (that is, project and reference). Trends in project and reference station FQI scores were compared graphically (fig. 6). The productivity index (PI) trends for reference and project vegetation station groups are also compared graphically (fig. 7).

The FQI is variable within station type and between years as is shown in figure 6 . Within both project and reference sites floristic quality generally decreased after major disturbances (that is, drought in 1997 and Hurricane Rita in 2005) and increased following the disturbance. In most years, both the reference and the project FQI scores were below the ideal range (80, see table 5) for a brackish marsh in the chenier plain. The PI trends were similar to those of the FQI in that productivity decreased after major disturbances in 1997 and 2005 and increased following the disturbances (fig. 7). Both project and reference areas had PI levels below the ideal PI range (table 5). 


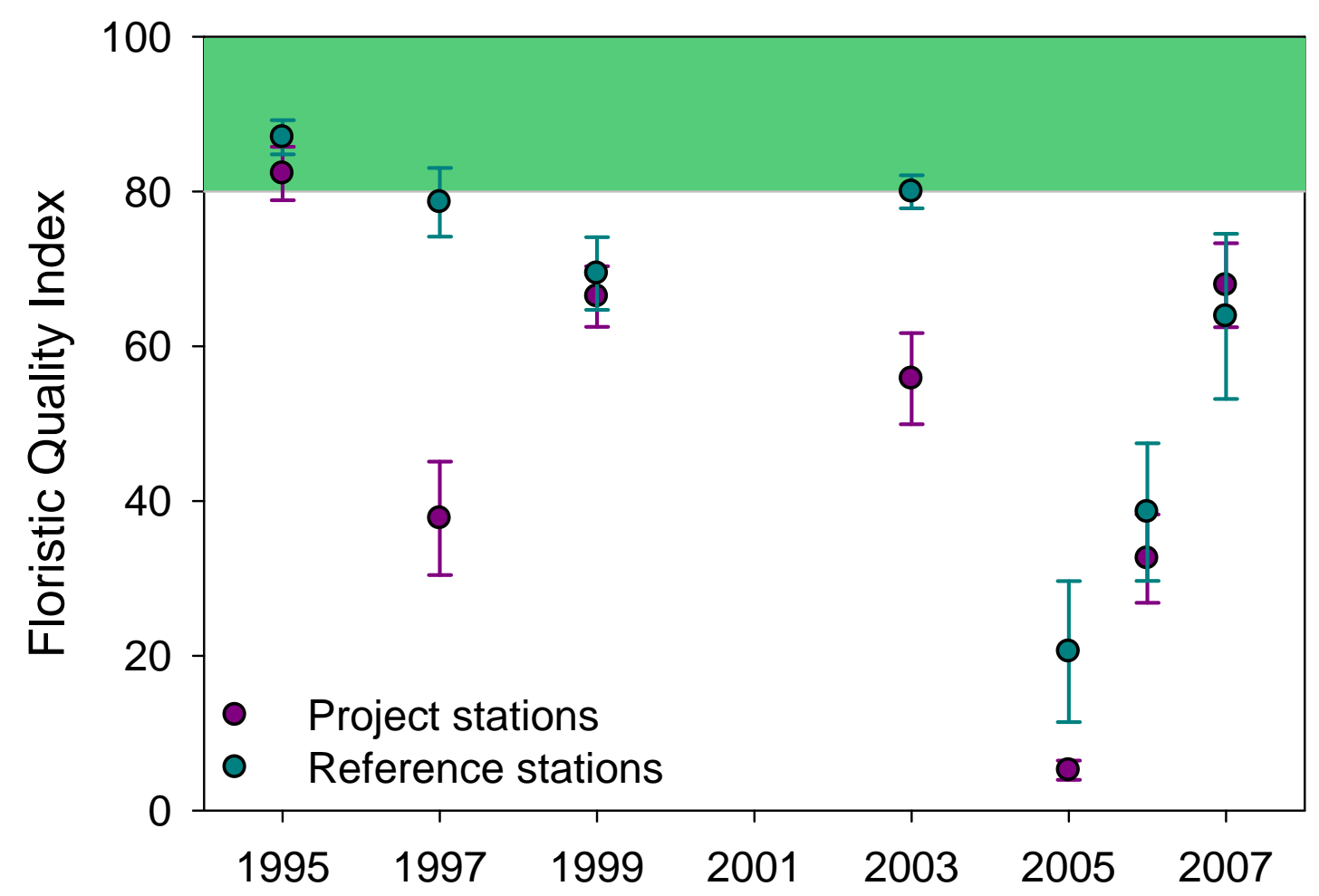

Figure 6. Mean ( \pm SE) floristic quality index scores for CS-20 project and reference stations by year. Green shaded area indicates ideal range for brackish marshes in the chenier plain. 


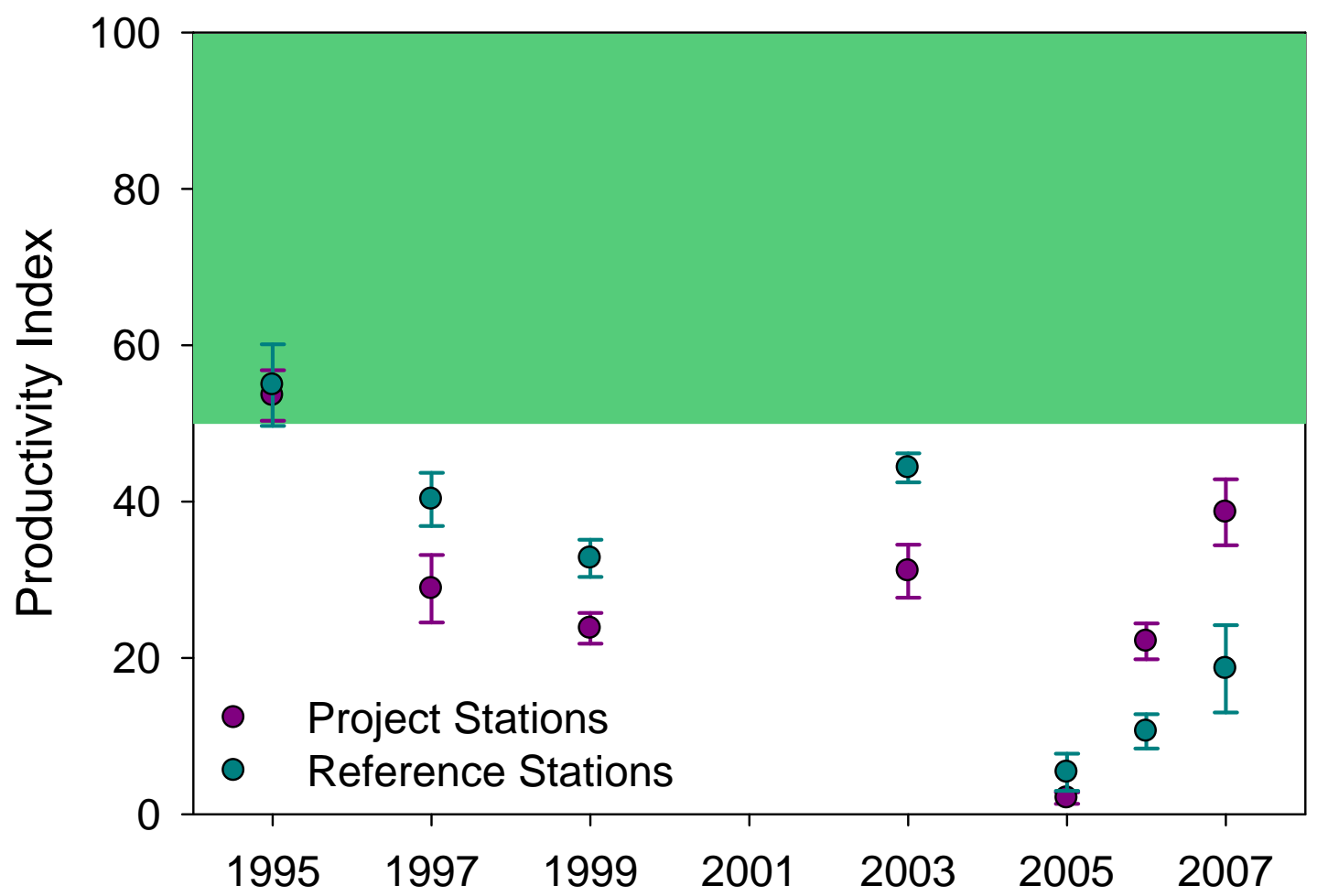

Figure 7. Mean ( \pm SE) productivity index scores for $\mathrm{CS}-20$ project and reference stations by year. Green shaded area indicates ideal range for brackish marshes in the chenier plain.

\section{Evaluation of Program Effectiveness}

\section{Vegetation Distribution}

Changes in marsh type within project sites will be compared to changes within reference sites across the entire coastal zone of Louisiana (landscape scale). Only projects for which construction has been completed more than 3 years before the CRMS survey year will be included as project sites. The CRMS sites are within the boundaries of coastwide vegetation surveys conducted in 1968 (Chabreck and others, 1968), 1997 (Chabreck and Linscombe, 1997), 2001 (Chabreck and Linscombe, 2001) and 2007 (Sasser and others, 2008); therefore, historical marsh types are available for the sites for those years. An algorithm based on species composition (Sasser and Visser, 2008) will be used to assign a marsh type to each CRMS site for all years where vegetation data is available. To determine marsh type change, the historical marsh type data from the 1968, 1997, 2001, and 2007 surveys will be compared to the marsh type data derived for the CRMS sites by using the algorithm.

If the CWPPRA projects have an effect on vegetation composition in the coastal zone, the analysis will show a statistical difference between the projects and reference sites. An example of the type of program-wide comparison expected is as follows: If $\mathrm{X}$ 
percent of the intermediate reference sites changed to brackish, did X percent of the project sites show the same change? Chi-square analysis will be used to determine if the amount of change is statistically different. This analysis will be done by using all stations coastwide and by hydrologic basin.

\section{Vegetation Condition}

Floristic quality and productivity indices alike have ideal ranges that differ by habitat type. Assessments of vegetation condition at landscape scales need to address these differences. Therefore, for each of the indices, we will use the difference between the site index and ideal range for its habitat type as an indicator of condition. Sites that are within the ideal range will be assigned a condition value of 1 . Sites that are below the ideal range will have their condition calculated as follows:

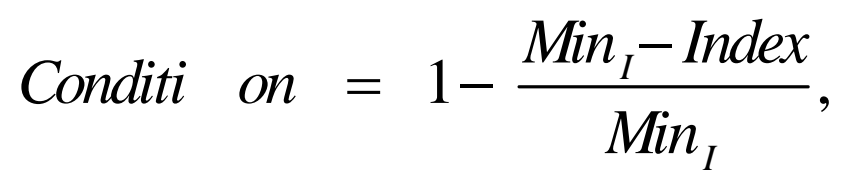

where MinI is the minimum value of the optimal range for the index and Index is either the FQI or Productivity index score. The condition calculated by using the FQI will be called the "floristic condition." The condition calculated by using the productivity index will be called "productivity condition.” A site will be evaluated relative to the ideal range for its habitat and relative to all other project and reference sites within the same habitat type and geological setting. A project site is a site that is within a project constructed at least 3 years prior to the vegetation survey. Descriptive statistics will be calculated for florisitc and productivity condition by site type (project and reference), habitat type, and geological setting to create a boxplot for each combination of site type, habitat type, and geological setting. Site floristic and productivity condition will be plotted with the appropriate boxplot to evaluate the status of the site. Because the ideal ranges are based on the best available data, these ranges may need to be adjusted as new data become available.

The project-scale floristic and productivity conditions will be used to create vegetation condition contour maps of the coast to provide a landscape view of vegetation condition and to identify regions of the coast with different levels of floristic or productivity condition. Regions with poor vegetation condition can then be highlighted so that the cause(s) of poor performance can be determined. With multiple years of data, changes in vegetation condition over time can be shown in relationship to project areas and project types. This update will provide an assessment of projects and identify projects that have improved vegetation condition relative to reference areas as well as projects that need improvement. 


\section{References}

Allain, L., Smith, L., Allen, C., Vidrine, M.F., and Grace, J.B., 2006, A floristic quality assessment system for the coastal prairie of Louisiana: Madison, Wis., Proceedings of the 19th North American Prairie Conference, August 8-12, 2004, p. 1-18.

Andreas, B.K., and Lichvar, R.W., 1995, Floristic index for assessment standards-a case study for northern Ohio: Vicksburg, Miss., U.S. Army Corps of EngineersWetlands Research Program Technical Report WRP-DE-8.

Andreas, B.K., Mack, J.J., and McCormac, J.J., 2004, Floristic quality assessment index (FQAI) for vascular plants and mosses for the state of Ohio: Columbus, Ohio, Ohio Environmental Protection Agency, Division of Surface Water, Wetland Ecology Group. 219 p.

Bourdaghs, M., Johnston, C.A., and Regal, R.R., 2006, Properties and performance of the floristic quality index in Great Lakes coastal wetlands: Wetlands, v. 26, p. 718735.

Chabreck, R. H., Joanen, T., and Palmisano, A.W., 1968, Vegetation type map of the Louisiana coastal marshes: New Orleans, La., Louisiana Wildlife and Fisheries Commission.

Chabreck, R.H., and Linscombe, G., 1997, Vegetation type map of the Louisiana coastal marshes: New Orleans, La., Louisiana Department of Wildlife and Fisheries.

Chabreck, R. H., and Linscombe, G., 2001, Louisiana coastal marsh vegetation map: Baton Rouge, La., Louisiana State University and Louisiana Department of Natural Resources.

Cohen, M.J., Carstenn, S., and Lane, C.R., 2004, Floristic quality indices for biotic assessment of depressional marsh condition in Florida: Ecological Applications, v. 14, p. 784-794.

Daoust, R.J., and Childers, D.L., 1998, Quantifying aboveground biomass and estimating net aboveground primary production for wetland macrophytes using a nondestructive phenometric technique: Aquatic Botany, v. 62, p. 115-133.

Ervin, G.N., Herman, B.D., Bried, J.T., and Holly, D.C., 2006, Evaluating non-native species and wetland indicator status as components of wetlands floristic assessment: Wetlands, v. 26, p.1114-1129.

Folse, T.M., West, J.L., Hymel, M.K., Troutman, J.P., Sharp, L., Weifenbach, D., McGinnis, T., and Rodrigue, L.B., 2008, A standard operating procedures manual for the Coast-wide Reference Monitoring System-Wetlands: methods for site establishment, data collection, and quality assurance/quality control: Baton Rouge, La., Louisiana Coastal Protection and Restoration Authority, Office of Coastal Protection and Restoration, $191 \mathrm{p}$.

Herman, B., 2005, Testing the floristic quality assessment index in natural and created wetlands in Mississippi, USA: M.S. Thesis. Mississippi State, Miss., Mississippi State University.

Hopkinson, C.S., Gosselink, J.G., and Parrondo R.T., 1980, Production of coastal Louisiana marsh plants calculated from phenometric techniques: Ecology, v. 61, p. 1091-1098. 
Krauss, K.W., Duberstein, J.A., Doyle, T.W., Conner, W.H., Day, R.H., Inabinette, L.W., and Whitbeck, J.L., 2009, Site condition, structure, and growth of baldcypress along tidal/non-tidal salinity gradients: Wetlands, v. 29, p.505-519.

Lopez, R.D., and Fennessy, M.S.. 2002, Testing the floristic quality assessment index as an indicator of wetland condition: Ecological Applications, v. 12, p. 487-497.

McKee, K.M., Cahoon, D.R., and Feller, I.C., 2007, Caribbean mangroves adjust to rising sea level through biotic controls on change in soil elevation: Global Ecology and Biogeography, v. 16, p. 545-556.

Megonigal, J.P., Conner, W.H., Kroeger, S., and Sharitz, R.S., 1997, Aboveground production in southeastern floodplain forests: a test of the subsidy-stress hypothesis: Ecology, v. 78, p. 370-384.

Miller, S.J. and Wardrop, D.H., 2006, Adapting the floristic quality assessment index to indicate anthropogenic disturbance in central Pennsylvania wetlands: Ecological Indicators, v. 6, p. 313-326.

Poling, T.C., Banker, M.G., and Jablonski, L.M., 2003, Quadrat-level floristic quality index reflects shifts in composition of a restored tallgrass prairie (Ohio): Ecological Restoration, v.21, p. 144-145.

Sasser, C.E. and Visser, J.M., 2008, Coastwide vegetation data collection project: final report: Baton Rouge, La., Louisiana State University Agricultural Center.

Sasser, C.E., Visser, J.M., Mouton, E., Linscombe, J., and Hartley, S.B., 2008, Vegetation types in coastal Louisiana in 2007: U.S. Geological Survey Open-File Report 2008-1224, 1 sheet, scale 1:550,000, http://pubs.usgs.gov/of/2008/1224/, accessed April 2009.

Steyer, G.D., Sasser, C.E., Visser, J.M., Swenson, E.M., Nyman, J.A., and Raynie, R.C., 2003, A proposed coast-wide reference monitoring system for evaluating wetland restoration trajectories in Louisiana: Environmental Monitoring and Assessment, v. 81, p. 107-117.

Steyer, G.D., Twilley, R.R., and Raynie, R.C., 2006, An integrated monitoring approach using multiple reference sites to assess sustainable restoration in coastal Louisiana: USDA Forest Service Proceedings RMRS-P-42CD, 8 p.

Swink, F. and Wilhelm, G.S., 1979, Plants of the Chicago region, third ed., revised and expanded edition with keys: Lisle, Ill. The Morton Arboretum,

U.S. Department of Agriculture (USDA), Natural Resource Conservation Service (NRCS), 2008, The PLANTS Database: Baton Rouge, La., National Plant Data Center, http://usda.plants.gov, accessed 2008 


\section{Appendix. Plant Species That Occur in Marshes and Forested Wetlands in Coastal Louisiana}

\section{Appendix Table. Plant species that occur in marshes and forested wetlands in coastal Louisiana}

[CC, Cofficient of Conservatism score (0-10) assigned by the coastal Louisiana vegetation expert panel; N, species that are native to the contiguous 48 States of the United States; I, species that are introduced; A, annual; P, perennial; B, biennial, following the U.S. Department of Agriculture's PLANTS Database (USDA, NRCS, 2008); †CC, score when the given species occurs in fresh and intermediate marshes; $\neq C C$, score when the given species occurs in brackish and saline marshes]

\begin{tabular}{|c|c|c|c|c|c|}
\hline Scientific name & $\mathrm{CC}$ & Origin & Duration & Form & Family \\
\hline Acer L. & 6 & & & & Aceraceae \\
\hline Acer negundo L. & 6 & $\mathrm{~N}$ & $\mathrm{P}$ & Tree & Aceraceae \\
\hline Acer rubrum L. & 7 & $\mathrm{~N}$ & $\mathrm{P}$ & Tree & Aceraceae \\
\hline Acer saccharinum L. & 6 & $\mathrm{~N}$ & $\mathrm{P}$ & Tree & Aceraceae \\
\hline Acer saccharum Marsh. & 6 & $\mathrm{~N}$ & $\mathrm{P}$ & Tree & Aceraceae \\
\hline Acmella L.C. Rich. ex Pers. & 3 & & & & Asteraceae \\
\hline Acmella oppositifolia (Lam.) R.K. Jansen & 3 & $\mathrm{~N}$ & $\mathrm{P}$ & Herb & Asteraceae \\
\hline Aeschynomene L. & 3 & & & & Fabaceae \\
\hline Aeschynomene americana L. & 3 & $\mathrm{~N}$ & $\mathrm{P}$ & Subshrub & Fabaceae \\
\hline Aeschynomene indica L. & 3 & $\mathrm{~N}$ & A & Subshrub & Fabaceae \\
\hline Agalinis Raf. & 6 & & & & Scrophulariaceae \\
\hline Agalinis fasciculata (Ell.) Raf. & 6 & $\mathrm{~N}$ & A & Herb & Scrophulariaceae \\
\hline Agalinis harperi Pennell & 5 & & & & Scrophulariaceae \\
\hline Agalinis heterophylla (Nutt.) Small ex Britt. & 6 & $\mathrm{~N}$ & A & Herb & Scrophulariaceae \\
\hline Agalinis maritima (Raf.) Raf. & 7 & $\mathrm{~N}$ & A & Herb & Scrophulariaceae \\
\hline Agalinis purpurea (L.) Pennell & 6 & $\mathrm{~N}$ & A & Herb & Scrophulariaceae \\
\hline Agrostis L. & 3 & & & & Poaceae \\
\hline
\end{tabular}




\section{Appendix Table. Plant species that occur in marshes and forested wetlands in coastal Louisiana.}

[CC, Cofficient of Conservatism score (0-10) assigned by the coastal Louisiana vegetation expert panel; $\mathrm{N}$, species that are native to the contiguous 48 States of the United States; I, species that are introduced; A, annual; P, perennial; B, biennial, following the U.S. Department of Agriculture's PLANTS Database (USDA, NRCS, 2008); †CC, score when the given species occurs in fresh and intermediate marshes; ¥CC, score when the given species occurs in brackish and saline marshes]

\begin{tabular}{lccccc}
\hline \multicolumn{1}{c}{ Scientific name } & CC & Origin & Duration & Form & Family \\
\hline Agrostis hyemalis (Walt.) B.S.P. & 3 & $\mathrm{~N}$ & $\mathrm{P}$ & Graminoid & Poaceae \\
Alopecurus L. & 1 & & & & Poaceae \\
Alopecurus carolinianus Walt. & 1 & $\mathrm{~N}$ & $\mathrm{~A}$ & Graminoid & Poaceae \\
Alternanthera Forsk. & 0 & & & & Amaranthaceae \\
Alternanthera philoxeroides (Mart.) Griseb. & 0 & $\mathrm{I}$ & $\mathrm{P}$ & Herb & Amaranthaceae \\
Amaranthus L. & 2 & & & & Amaranthaceae \\
Amaranthus albus L. & 0 & $\mathrm{I}$ & $\mathrm{A}$ & Herb & Amaranthaceae \\
Amaranthus australis (Gray) Sauer & 2 & $\mathrm{~N}$ & $\mathrm{~A}$ & Herb & Amaranthaceae \\
Amaranthus bigelovii Uline \& Bray & 2 & $\mathrm{~N}$ & $\mathrm{~A}$ & Herb & Amaranthaceae \\
Amaranthus cannabinus (L.) Sauer & 2 & $\mathrm{~N}$ & $\mathrm{P}$ & Herb & Amaranthaceae \\
Amaranthus spinosus L. & 2 & $\mathrm{~N}$ & $\mathrm{~A}$ & Herb & Amaranthaceae \\
Amaranthus tuberculatus (Moq.) Sauer & 2 & $\mathrm{~N}$ & $\mathrm{~A}$ & Herb & Amaranthaceae \\
Ambrosia L. L. & 2 & & & Asteraceae \\
Ambrosia artemisiifolia L. & 2 & $\mathrm{~N}$ & $\mathrm{~A}$ & Herb & Asteraceae \\
Ambrosia psilostachya DC. & 2 & $\mathrm{~N}$ & $\mathrm{~A}$ & Herb & Asteraceae \\
Ambrosia trifida L. & 2 & $\mathrm{~N}$ & $\mathrm{~A}$ & Herb & Asteraceae \\
Ammannia L. & 4 & & & Lythraceae \\
Ammannia auriculata Willd. & 4 & $\mathrm{~N}$ & $\mathrm{~A}$ & Herb & Lythraceae \\
Ammannia coccinea Rottb. & 4 & $\mathrm{~N}$ & $\mathrm{~A}$ & Herb & Lythraceae \\
Ammannia latifolia L. & 4 & $\mathrm{~N}$ & $\mathrm{~A}$ & Herb & Lythraceae
\end{tabular}




\section{Appendix Table. Plant species that occur in marshes and forested wetlands in coastal Louisiana.}

[CC, Cofficient of Conservatism score (0-10) assigned by the coastal Louisiana vegetation expert panel; $\mathrm{N}$, species that are native to the contiguous 48 States of the United States; I, species that are introduced; A, annual; P, perennial; B, biennial, following the U.S. Department of Agriculture's PLANTS Database (USDA, NRCS, 2008); †CC, score when the given species occurs in fresh and intermediate marshes; ¥CC, score when the given species occurs in brackish and saline marshes]

\begin{tabular}{lccccc}
\hline \multicolumn{1}{c}{ Scientific name } & CC & Origin & Duration & Form & Family \\
\hline Ampelopsis Michx. & 4 & & & & Vitaceae \\
Ampelopsis arborea (L.) Koehne & 5 & $\mathrm{~N}$ & $\mathrm{P}$ & Vine & Vitaceae \\
Ampelopsis cordata Michx. & 4 & $\mathrm{~N}$ & $\mathrm{P}$ & Vine & Vitaceae \\
Anagallis L. & 2 & & & & Primulaceae \\
Anagallis minima (L.) Krause & 2 & $\mathrm{~N}$ & $\mathrm{~A}$ & Herb & Primulaceae \\
Andropogon L. & 3 & & & & Poaceae \\
Andropogon capillipes Nash & 3 & $\mathrm{~N}$ & $\mathrm{P}$ & Graminoid & Poaceae \\
Andropogon gerardii Vitman & 3 & & & & Poaceae \\
Andropogon glaucopsis Ell. & 3 & $\mathrm{~N}$ & $\mathrm{P}$ & Graminoid & Poaceae \\
Andropogon glomeratus (Walt.) B.S.P. & 3 & $\mathrm{~N}$ & $\mathrm{P}$ & Graminoid & Poaceae \\
Andropogon mohrii (Hack.) Hack. ex Vasey & 3 & $\mathrm{~N}$ & $\mathrm{P}$ & Graminoid & Poaceae \\
Andropogon virginicus L. & 3 & $\mathrm{~N}$ & $\mathrm{P}$ & Graminoid & Poaceae \\
Apios Fabr. & 5 & & & & Fabaceae \\
Apios americana Medik. & 5 & $\mathrm{~N}$ & $\mathrm{P}$ & Vine & Fabaceae \\
Arisaema Mart. & 4 & & & Araceae \\
Arisaema dracontium (L.) Schott & 4 & $\mathrm{~N}$ & $\mathrm{P}$ & Herb & Araceae \\
Arundinaria Michx. & 5 & & & Poaceae \\
Arundinaria gigantea (Walt.) Muhl. & 5 & $\mathrm{~N}$ & $\mathrm{P}$ & Graminoid & Poaceae \\
Asclepias L. & 7 & & & Asclepiadaceae \\
Asclepias incarnata L. & 7 & $\mathrm{~N}$ & $\mathrm{P}$ & Herb & Asclepiadaceae
\end{tabular}




\section{Appendix Table. Plant species that occur in marshes and forested wetlands in coastal Louisiana.}

[CC, Cofficient of Conservatism score (0-10) assigned by the coastal Louisiana vegetation expert panel; $\mathrm{N}$, species that are native to the contiguous 48 States of the United States; I, species that are introduced; A, annual; P, perennial; B, biennial, following the U.S. Department of Agriculture's PLANTS Database (USDA, NRCS, 2008); †CC, score when the given species occurs in fresh and intermediate marshes; ¥CC, score when the given species occurs in brackish and saline marshes]

\begin{tabular}{|c|c|c|c|c|c|}
\hline Scientific name & CC & Origin & Duration & Form & Family \\
\hline Asclepias lanceolata Walt. & 8 & $\mathrm{~N}$ & $\mathrm{P}$ & Herb & Asclepiadaceae \\
\hline Asclepias longifolia Michx. & 7 & $\mathrm{~N}$ & $\mathrm{P}$ & Herb & Asclepiadaceae \\
\hline Asclepias perennis Walt. & 7 & $\mathrm{~N}$ & $\mathrm{P}$ & Herb & Asclepiadaceae \\
\hline Atriplex L. & 3 & & & & Chenopodiaceae \\
\hline Atriplex cristata Humb. \& Bonpl. ex Willd. & 3 & $\mathrm{~N}$ & A & Herb & Chenopodiaceae \\
\hline Avicennia L. & 10 & & & & Verbenaceae \\
\hline Avicennia germinans (L.) L. & 10 & $\mathrm{~N}$ & $\mathrm{P}$ & Shrub & Verbenaceae \\
\hline Axonopus Beauv. & 2 & & & & Poaceae \\
\hline Axonopus fissifolius (Raddi) Kuhlm. & 2 & $\mathrm{~N}$ & $\mathrm{P}$ & Graminoid & Poaceae \\
\hline Baccharis L. & 5 & & & & Asteraceae \\
\hline Baccharis angustifolia Michx. & 5 & $\mathrm{~N}$ & $\mathrm{P}$ & Shrub & Asteraceae \\
\hline Baccharis halimifolia L. & 4 & $\mathrm{~N}$ & $\mathrm{P}$ & Shrub & Asteraceae \\
\hline Bacopa Aubl. & 5 & & & & Scrophulariaceae \\
\hline Bacopa caroliniana (Walt.) B.L. Robins. & 5 & $\mathrm{~N}$ & $\mathrm{P}$ & Herb & Scrophulariaceae \\
\hline Bacopa monnieri (L.) Pennell & 5 & $\mathrm{~N}$ & $\mathrm{P}$ & Herb & Scrophulariaceae \\
\hline Bacopa repens (Sw.) Wettst. & 4 & $\mathrm{~N}$ & $\mathrm{P}$ & Herb & Scrophulariaceae \\
\hline Bacopa rotundifolia (Michx.) Wettst. & 4 & $\mathrm{~N}$ & $\mathrm{P}$ & Herb & Scrophulariaceae \\
\hline Batis P. Br. & 5 & & & & Bataceae \\
\hline Batis maritima $\mathrm{L}$. & 5 & $\mathrm{~N}$ & $\mathrm{P}$ & Subshrub & Bataceae \\
\hline Berchemia Neck. ex DC. & 6 & & & & Rhamnaceae \\
\hline
\end{tabular}




\section{Appendix Table. Plant species that occur in marshes and forested wetlands in coastal Louisiana.}

[CC, Cofficient of Conservatism score (0-10) assigned by the coastal Louisiana vegetation expert panel; $\mathrm{N}$, species that are native to the contiguous 48 States of the United States; I, species that are introduced; A, annual; P, perennial; B, biennial, following the U.S. Department of Agriculture's PLANTS Database (USDA, NRCS, 2008); †CC, score when the given species occurs in fresh and intermediate marshes; ¥CC, score when the given species occurs in brackish and saline marshes]

\begin{tabular}{|c|c|c|c|c|c|}
\hline Scientific name & $\mathrm{CC}$ & Origin & Duration & Form & Family \\
\hline Berchemia scandens (Hill) K. Koch & 6 & $\mathrm{~N}$ & $\mathrm{P}$ & Vine & Rhamnaceae \\
\hline Bidens L. & 3 & & & & Asteraceae \\
\hline Bidens aristosa (Michx.) Britt. & 3 & & & & Asteraceae \\
\hline Bidens laevis (L.) B.S.P. & 3 & $\mathrm{~N}$ & A & Herb & Asteraceae \\
\hline Bignonia L. & 5 & & & & Bignoniaceae \\
\hline Bignonia capreolata L. & 5 & $\mathrm{~N}$ & $\mathrm{P}$ & Vine & Bignoniaceae \\
\hline Blutaparon Raf. & 5 & & & & Amaranthaceae \\
\hline Blutaparon vermiculare (L.) Mears & 5 & $\mathrm{~N}$ & $\mathrm{P}$ & Herb & Amaranthaceae \\
\hline Boehmeria cylindrica (L.) Sw. & 4 & $\mathrm{~N}$ & $\mathrm{P}$ & Herb & Urticaceae \\
\hline Boehmeria nivea (L.) Gaud. & 0 & I & $\mathrm{P}$ & Herb & Urticaceae \\
\hline Boltonia L'Hér. & 5 & & & & Asteraceae \\
\hline Boltonia asteroides (L.) L'Her. & 5 & $\mathrm{~N}$ & $\mathrm{P}$ & Herb & Asteraceae \\
\hline Boltonia diffusa Ell. & 5 & $\mathrm{~N}$ & $\mathrm{P}$ & Herb & Asteraceae \\
\hline Borrichia Adans. & 7 & & & & Asteraceae \\
\hline Borrichia frutescens (L.) DC. & 7 & $\mathrm{~N}$ & $\mathrm{P}$ & Subshrub & Asteraceae \\
\hline Brunnichia Banks ex Gaertn. & 4 & & & & Polygonaceae \\
\hline Brunnichia ovata (Walt.) Shinners & 4 & $\mathrm{~N}$ & $\mathrm{P}$ & Vine & Polygonaceae \\
\hline Cakile P. Mill. & 2 & & & & Brassicaceae \\
\hline Cakile constricta Rodman & 7 & $\mathrm{~N}$ & A & Herb & Brassicaceae \\
\hline Cakile geniculata (B.L. Robins.) Millsp. & 6 & $\mathrm{~N}$ & A & Herb & Brassicaceae \\
\hline
\end{tabular}




\section{Appendix Table. Plant species that occur in marshes and forested wetlands in coastal Louisiana.}

[CC, Cofficient of Conservatism score (0-10) assigned by the coastal Louisiana vegetation expert panel; $\mathrm{N}$, species that are native to the contiguous 48 States of the United States; I, species that are introduced; A, annual; P, perennial; B, biennial, following the U.S. Department of Agriculture's PLANTS Database (USDA, NRCS, 2008); †CC, score when the given species occurs in fresh and intermediate marshes; ¥CC, score when the given species occurs in brackish and saline marshes]

\begin{tabular}{|c|c|c|c|c|c|}
\hline Scientific name & $\mathbf{C C}$ & Origin & Duration & Form & Family \\
\hline Caladium Vent. & 0 & & & & Araceae \\
\hline Caladium bicolor (Ait.) Vent. & 0 & I & $\mathrm{P}$ & Herb & Araceae \\
\hline Calystegia R. Br. & 0 & & & & Convolvulaceae \\
\hline Calystegia sepium (L.) R. Br. & 0 & $\mathrm{I}$ & $\mathrm{P}$ & Vine & Convolvulaceae \\
\hline Campsis Lour. & 4 & & & & Bignoniaceae \\
\hline Cardamine L. & 1 & & & & Brassicaceae \\
\hline Cardamine hirsuta L. & 0 & I & A & Herb & Brassicaceae \\
\hline Cardamine pensylvanica Muhl. ex Willd. & 2 & $\mathrm{~N}$ & A & Herb & Brassicaceae \\
\hline Carex alata Torr. & 3 & $\mathrm{~N}$ & $\mathrm{P}$ & Graminoid & Сyperaceae \\
\hline Carex albolutescens Schwein. & 3 & $\mathrm{~N}$ & $\mathrm{P}$ & Graminoid & Cyperaceae \\
\hline Carex cherokeensis Schwein. & 3 & $\mathrm{~N}$ & $\mathrm{P}$ & Graminoid & Cyperaceae \\
\hline Carex crus-corvi Shuttlw. ex Kunze & 5 & $\mathrm{~N}$ & $\mathrm{P}$ & Graminoid & Cyperaceae \\
\hline Carex frankii Kunth & 3 & $\mathrm{~N}$ & $\mathrm{P}$ & Graminoid & Cyperaceae \\
\hline Carex glaucescens Ell. & 7 & $\mathrm{~N}$ & $\mathrm{P}$ & Graminoid & Cyperaceae \\
\hline Carex hyalinolepis Steud. & 5 & $\mathrm{~N}$ & $\mathrm{P}$ & Graminoid & Сyperaceae \\
\hline Carex longii Mackenzie & 6 & $\mathrm{~N}$ & $\mathrm{P}$ & Graminoid & Cyperaceae \\
\hline Carex lupulina Muhl. ex Willd. & 5 & $\mathrm{~N}$ & $\mathrm{P}$ & Graminoid & Cyperaceae \\
\hline Carex triangularis Boeckl. & 6 & $\mathrm{~N}$ & $\mathrm{P}$ & Graminoid & Cyperaceae \\
\hline
\end{tabular}




\section{Appendix Table. Plant species that occur in marshes and forested wetlands in coastal Louisiana.}

[CC, Cofficient of Conservatism score (0-10) assigned by the coastal Louisiana vegetation expert panel; $\mathrm{N}$, species that are native to the contiguous 48 States of the United States; I, species that are introduced; A, annual; P, perennial; B, biennial, following the U.S. Department of Agriculture's PLANTS Database (USDA, NRCS, 2008); †CC, score when the given species occurs in fresh and intermediate marshes; ¥CC, score when the given species occurs in brackish and saline marshes]

\begin{tabular}{|c|c|c|c|c|c|}
\hline Scientific name & $\mathrm{CC}$ & Origin & Duration & Form & Family \\
\hline Carex tribuloides Wahlenb. & 5 & $\mathrm{~N}$ & $\mathrm{P}$ & Graminoid & Cyperaceae \\
\hline Carex vulpinoidea Michx. & 5 & $\mathrm{~N}$ & $\mathrm{P}$ & Graminoid & Cyperaceae \\
\hline Carya Nutt. & 8 & & & & Juglandaceae \\
\hline Carya aquatica (Michx. f.) Nutt. & 8 & $\mathrm{~N}$ & $\mathrm{P}$ & Tree & Juglandaceae \\
\hline Catalpa Scop. & 7 & & & & Bignoniaceae \\
\hline Catalpa bignonioides Walt. & 7 & $\mathrm{~N}$ & $\mathrm{P}$ & Tree & Bignoniaceae \\
\hline Celtis L. & 7 & & & & Ulmaceae \\
\hline Celtis laevigata Willd. & 7 & $\mathrm{~N}$ & $\mathrm{P}$ & Tree & Ulmaceae \\
\hline Centella L. & 4 & & & & Apiaceae \\
\hline Centella erecta (L. f.) Fern. & 4 & $\mathrm{~N}$ & $\mathrm{P}$ & Herb & Apiaceae \\
\hline Cephalanthus L. & 6 & & & & Rubiaceae \\
\hline Cephalanthus occidentalis L. & 6 & $\mathrm{~N}$ & $\mathrm{P}$ & Shrub & Rubiaceae \\
\hline Chaerophyllum L. & 2 & & & & Apiaceae \\
\hline Chaerophyllum tainturieri Hook. & 2 & $\mathrm{~N}$ & A & Herb & Apiaceae \\
\hline Chasmanthium Link & 6 & & & & Poaceae \\
\hline Chasmanthium latifolium (Michx.) Yates & 6 & $\mathrm{~N}$ & $\mathrm{P}$ & Graminoid & Poaceae \\
\hline Chasmanthium laxum (L.) Yates & 6 & $\mathrm{~N}$ & $\mathrm{P}$ & Graminoid & Poaceae \\
\hline Chenopodium L. & 0 & & & & Chenopodiaceae \\
\hline Chenopodium album L. & 0 & I & $\mathrm{A}$ & Herb & Chenopodiaceae \\
\hline Chenopodium ambrosioides L. & 0 & I & $\mathrm{A}$ & Subshrub & Chenopodiaceae \\
\hline
\end{tabular}




\section{Appendix Table. Plant species that occur in marshes and forested wetlands in coastal Louisiana.}

[CC, Cofficient of Conservatism score (0-10) assigned by the coastal Louisiana vegetation expert panel; $\mathrm{N}$, species that are native to the contiguous 48 States of the United States; I, species that are introduced; A, annual; P, perennial; B, biennial, following the U.S. Department of Agriculture's PLANTS Database (USDA, NRCS, 2008); †CC, score when the given species occurs in fresh and intermediate marshes; ¥CC, score when the given species occurs in brackish and saline marshes]

\begin{tabular}{|c|c|c|c|c|c|}
\hline Scientific name & $\mathrm{CC}$ & Origin & Duration & Form & Family \\
\hline Chloracantha Nesom & 7 & & & & Asteraceae \\
\hline Chloracantha spinosa (Benth.) Nesom & 7 & $\mathrm{~N}$ & $\mathrm{P}$ & Subshrub & Asteraceae \\
\hline Cicuta L. & 5 & & & & Apiaceae \\
\hline Cicuta maculata L. & 5 & $\mathrm{~N}$ & B & Herb & Apiaceae \\
\hline Cinnamomum Schaeffer & 0 & & & & Lauraceae \\
\hline Cinnamomum camphora (L.) J. Presl & 0 & I & $\mathrm{P}$ & Tree & Lauraceae \\
\hline Cirsium P. Mill. & 2 & & & & Asteraceae \\
\hline Cirsium horridulum Michx. & 2 & $\mathrm{~N}$ & A & Herb & Asteraceae \\
\hline Cirsium muticum Michx. & 2 & $\mathrm{~N}$ & B & Herb & Asteraceae \\
\hline Cissus L. & 5 & & & & Vitaceae \\
\hline Cissus trifoliata (L.) L. & 5 & $\mathrm{~N}$ & $\mathrm{P}$ & Vine & Vitaceae \\
\hline Cladium P. Br. & 8 & & & & Cyperaceae \\
\hline Cladium mariscus (L.) Pohl & 8 & $\mathrm{~N}$ & $\mathrm{P}$ & Graminoid & Cyperaceae \\
\hline Clematis L. & 6 & & & & Ranunculaceae \\
\hline Clematis crispa L. & 6 & $\mathrm{~N}$ & $\mathrm{P}$ & Vine & Ranunculaceae \\
\hline Clitoria L. & 6 & & & & Fabaceae \\
\hline Clitoria mariana L. & 6 & $\mathrm{~N}$ & $\mathrm{P}$ & Vine & Fabaceae \\
\hline Colocasia Schott & 0 & & & & Araceae \\
\hline Colocasia esculenta (L.) Schott & 0 & I & $\mathrm{P}$ & Herb & Araceae \\
\hline Commelina caroliniana Walt. & 0 & I & A & Herb & Commelinaceae \\
\hline
\end{tabular}




\section{Appendix Table. Plant species that occur in marshes and forested wetlands in coastal Louisiana.}

[CC, Cofficient of Conservatism score (0-10) assigned by the coastal Louisiana vegetation expert panel; $\mathrm{N}$, species that are native to the contiguous 48 States of the United States; I, species that are introduced; A, annual; P, perennial; B, biennial, following the U.S. Department of Agriculture's PLANTS Database (USDA, NRCS, 2008); †CC, score when the given species occurs in fresh and intermediate marshes; ¥CC, score when the given species occurs in brackish and saline marshes]

\begin{tabular}{|c|c|c|c|c|c|}
\hline Scientific name & $\mathrm{CC}$ & Origin & Duration & Form & Family \\
\hline Commelina communis L. & 0 & I & A & Herb & Commelinaceae \\
\hline Commelina diffusa Burm. f. & 3 & $\mathrm{~N}$ & A & Herb & Commelinaceae \\
\hline Commelina erecta $\mathrm{L}$. & 4 & $\mathrm{~N}$ & $\mathrm{P}$ & Herb & Commelinaceae \\
\hline Commelina virginica $\mathrm{L}$. & 5 & $\mathrm{~N}$ & $\mathrm{P}$ & Herb & Commelinaceae \\
\hline Conoclinium DC. & 3 & & & & Asteraceae \\
\hline Conoclinium coelestinum (L.) DC. & 3 & $\mathrm{~N}$ & $\mathrm{P}$ & Herb & Asteraceae \\
\hline Conyza Less. & 1 & & & & Asteraceae \\
\hline Conyza canadensis (L.) Cronq. & 1 & $\mathrm{~N}$ & A & Herb & Asteraceae \\
\hline Cornus L. & 6 & & & & Cornaceae \\
\hline Cornus florida L. & 6 & $\mathrm{~N}$ & $\mathrm{P}$ & Tree & Cornaceae \\
\hline Cornus foemina P. Mill. & 7 & $\mathrm{~N}$ & $\mathrm{P}$ & Tree & Cornaceae \\
\hline Cortaderia Stapf & 0 & & & & Poaceae \\
\hline Cortaderia selloana (J.A. \& J.H. Schultes) Aschers. \& Graebn. & 0 & & & & Poaceae \\
\hline Crataegus L. & 7 & & & & Rosaceae \\
\hline Crataegus viridis L. & 7 & $\mathrm{~N}$ & $\mathrm{P}$ & Tree & Rosaceae \\
\hline Crinum L. & 8 & & & & Liliaceae \\
\hline Crinum americanum L. & 8 & $\mathrm{~N}$ & $\mathrm{P}$ & Herb & Liliaceae \\
\hline Croton L. & 2 & & & & Euphorbiaceae \\
\hline Croton capitatus Michx. & 2 & $\mathrm{~N}$ & A & Herb & Euphorbiaceae \\
\hline Croton glandulosus L. & 2 & $\mathrm{~N}$ & A & Subshrub & Euphorbiaceae \\
\hline
\end{tabular}




\section{Appendix Table. Plant species that occur in marshes and forested wetlands in coastal Louisiana.}

[CC, Cofficient of Conservatism score (0-10) assigned by the coastal Louisiana vegetation expert panel; $\mathrm{N}$, species that are native to the contiguous 48 States of the United States; I, species that are introduced; A, annual; P, perennial; B, biennial, following the U.S. Department of Agriculture's PLANTS Database (USDA, NRCS, 2008); †CC, score when the given species occurs in fresh and intermediate marshes; ¥CC, score when the given species occurs in brackish and saline marshes]

\begin{tabular}{|c|c|c|c|c|c|}
\hline Scientific name & $\mathrm{CC}$ & Origin & Duration & Form & Family \\
\hline Croton monanthogynus Michx. & 3 & $\mathrm{~N}$ & A & Herb & Euphorbiaceae \\
\hline Croton punctatus Jacq. & 3 & $\mathrm{~N}$ & $\mathrm{P}$ & Subshrub & Euphorbiaceae \\
\hline Cynanchum L. & 6 & & & & Asclepiadaceae \\
\hline Cynanchum angustifolium Pers. & 6 & $\mathrm{~N}$ & $\mathrm{P}$ & Vine & Asclepiadaceae \\
\hline Cynanchum laeve (Michx.) Pers. & 6 & $\mathrm{~N}$ & $\mathrm{P}$ & Vine & Asclepiadaceae \\
\hline Cynodon L.C. Rich. & 0 & & & & Poaceae \\
\hline Cynodon dactylon (L.) Pers. & 0 & $\mathrm{I}$ & $\mathrm{P}$ & Graminoid & Poaceae \\
\hline Cyperus articulatus L. & 5 & $\mathrm{~N}$ & $\mathrm{P}$ & Graminoid & Cyperaceae \\
\hline Cyperus compressus L. & 2 & $\mathrm{~N}$ & $\mathrm{P}$ & Graminoid & Cyperaceae \\
\hline Cyperus difformis L. & 0 & I & A & Graminoid & Cyperaceae \\
\hline Cyperus elegans L. & 4 & $\mathrm{I}$ & A & Graminoid & Cyperaceae \\
\hline Cyperus erythrorhizos Muhl. & 3 & $\mathrm{~N}$ & $\mathrm{P}$ & Graminoid & Cyperaceae \\
\hline Cyperus esculentus L. & 0 & $\mathrm{~N}$ & A & Graminoid & Cyperaceae \\
\hline Cyperus filicinus Vahl & 4 & $\mathrm{~N}$ & A & Graminoid & Cyperaceae \\
\hline Cyperus flavescens L. & 2 & $\mathrm{~N}$ & A & Graminoid & Cyperaceae \\
\hline Cyperus haspan L. & 5 & $\mathrm{~N}$ & $\mathrm{P}$ & Graminoid & Cyperaceae \\
\hline Cyperus iria L. & 0 & $\mathrm{~N}$ & $\mathrm{P}$ & Graminoid & Cyperaceae \\
\hline Cyperus ochraceus Vahl & 4 & $\mathrm{~N}$ & $\mathrm{P}$ & Graminoid & Cyperaceae \\
\hline Cyperus odoratus L. & 4 & $\mathrm{~N}$ & $\mathrm{~A}$ & Graminoid & Cyperaceae \\
\hline Cyperus oxylepis Nees ex Steud. & 4 & $\mathrm{~N}$ & $\mathrm{P}$ & Graminoid & Сyperaceae \\
\hline
\end{tabular}




\section{Appendix Table. Plant species that occur in marshes and forested wetlands in coastal Louisiana.}

[CC, Cofficient of Conservatism score (0-10) assigned by the coastal Louisiana vegetation expert panel; $\mathrm{N}$, species that are native to the contiguous 48 States of the United States; I, species that are introduced; A, annual; P, perennial; B, biennial, following the U.S. Department of Agriculture's PLANTS Database (USDA, NRCS, 2008); †CC, score when the given species occurs in fresh and intermediate marshes; ¥CC, score when the given species occurs in brackish and saline marshes]

\begin{tabular}{llllll}
\hline \multicolumn{1}{c}{ Scientific name } & C & Origin & Duration & Form & Family \\
\hline Cyperus polystachyos Rottb. & 4 & $\mathrm{~N}$ & $\mathrm{~A}$ & Graminoid & Cyperaceae \\
Cyperus pseudovegetus Steud. & 4 & $\mathrm{~N}$ & $\mathrm{P}$ & Graminoid & Cyperaceae \\
Cyperus retrorsus Chapman & 6 & $\mathrm{~N}$ & $\mathrm{P}$ & Graminoid & Cyperaceae \\
Cyperus rotundus L. & 0 & $\mathrm{I}$ & $\mathrm{P}$ & Graminoid & Cyperaceae \\
Cyperus strigosus L. & 3 & $\mathrm{~N}$ & $\mathrm{P}$ & Graminoid & Cyperaceae \\
Cyperus surinamensis Rottb. & 4 & $\mathrm{~N}$ & $\mathrm{P}$ & Graminoid & Cyperaceae \\
Cyperus tetragonus Ell. & 3 & $\mathrm{~N}$ & $\mathrm{P}$ & Graminoid & Cyperaceae \\
Cyperus virens Michx. & 4 & $\mathrm{~N}$ & $\mathrm{P}$ & Graminoid & Cyperaceae \\
Decodon J.F. Gmel. & 6 & & & & Lythraceae \\
Decodon verticillatus (L.) Ell. & 6 & $\mathrm{~N}$ & $\mathrm{P}$ & Subshrub & Lythraceae \\
Dichanthelium (A.S. Hitchc. \& Chase) Gould & 6 & & & & Poaceae \\
Dichanthelium acuminatum (Sw.) Gould \& C.A. Clark & 4 & $\mathrm{~N}$ & $\mathrm{P}$ & Graminoid & Poaceae \\
Dichanthelium commutatum (J.A. Schultes) Gould & 5 & $\mathrm{~N}$ & $\mathrm{P}$ & Graminoid & Poaceae \\
Dichanthelium dichotomum (L.) Gould & 6 & $\mathrm{~N}$ & $\mathrm{P}$ & Graminoid & Poaceae \\
Dichanthelium scabriusculum (Ell.) Gould \& C.A. Clark & 7 & $\mathrm{~N}$ & $\mathrm{P}$ & Graminoid & Poaceae \\
Dichanthelium scoparium (Lam.) Gould & 5 & $\mathrm{~N}$ & $\mathrm{P}$ & Graminoid & Poaceae \\
Diodia L. & 2 & & & Rubiaceae \\
Diodia teres Walt. & 2 & $\mathrm{~N}$ & $\mathrm{~A}$ & Herb & Rubiaceae \\
Diodia virginiana L. & 2 & $\mathrm{~N}$ & $\mathrm{~A}$ & Herb & Rubiaceae \\
Diospyros L. & 7 & & & Ebenaceae
\end{tabular}




\section{Appendix Table. Plant species that occur in marshes and forested wetlands in coastal Louisiana.}

[CC, Cofficient of Conservatism score (0-10) assigned by the coastal Louisiana vegetation expert panel; $\mathrm{N}$, species that are native to the contiguous 48 States of the United States; I, species that are introduced; A, annual; P, perennial; B, biennial, following the U.S. Department of Agriculture's PLANTS Database (USDA, NRCS, 2008); †CC, score when the given species occurs in fresh and intermediate marshes; ¥CC, score when the given species occurs in brackish and saline marshes]

\begin{tabular}{llllll}
\hline \multicolumn{1}{c}{ Scientific name } & CC & Origin & Duration & Form & Family \\
\hline Diospyros virginiana L. & 7 & $\mathrm{~N}$ & $\mathrm{P}$ & Tree & Ebenaceae \\
Distichlis spicata (L.) Greene & $2^{\dagger}, 9^{\ddagger}$ & $\mathrm{N}$ & $\mathrm{P}$ & Graminoid & Poaceae \\
Echinochloa Beauv. & 3 & & & & Poaceae \\
Echinochloa colona (L.) Link & 0 & $\mathrm{I}$ & $\mathrm{A}$ & Graminoid & Poaceae \\
Echinochloa crus-galli (L.) Beauv. & 0 & $\mathrm{I}$ & $\mathrm{A}$ & Graminoid & Poaceae \\
Echinochloa muricata (Beauv.) Fern. & 3 & $\mathrm{~N}$ & $\mathrm{~A}$ & Graminoid & Poaceae \\
Echinochloa polystachya (Kunth) A.S. Hitchc. & 5 & $\mathrm{~N}$ & $\mathrm{P}$ & Graminoid & Poaceae \\
Echinochloa walteri (Pursh) Heller & 5 & $\mathrm{~N}$ & $\mathrm{~A}$ & Graminoid & Poaceae \\
Echinodorus L.C. Rich. ex Engelm. & 5 & & & & Alismataceae \\
Echinodorus berteroi (Spreng.) Fassett & 5 & $\mathrm{~N}$ & $\mathrm{P}$ & Herb & Alismataceae \\
Echinodorus cordifolius (L.) Griseb. & 5 & $\mathrm{~N}$ & $\mathrm{P}$ & Herb & Alismataceae \\
Eclipta L. & 3 & & & & Asteraceae \\
Eclipta prostrata (L.) L. & 3 & $\mathrm{~N}$ & $\mathrm{~A}$ & Herb & Asteraceae \\
Egeria Planch. & 0 & & & Hydrocharitaceae \\
Egeria densa Planch. & 0 & $\mathrm{I}$ & $\mathrm{P}$ & Herb & Hydrocharitaceae \\
Eleocharis acicularis (L.) Roemer \& J.A. Schultes & 3 & $\mathrm{~N}$ & $\mathrm{~A}$ & Graminoid & Cyperaceae \\
Eleocharis albida Torr. & 5 & $\mathrm{~N}$ & $\mathrm{P}$ & Graminoid & Cyperaceae \\
Eleocharis baldwinii (Torr.) Chapman & 5 & $\mathrm{~N}$ & $\mathrm{P}$ & Graminoid & Cyperaceae \\
Eleocharis cellulosa Torr. & 7 & $\mathrm{~N}$ & $\mathrm{P}$ & Graminoid & Cyperaceae \\
Eleocharis elongata Chapman & 5 & $\mathrm{~N}$ & $\mathrm{P}$ & Graminoid & Cyperaceae
\end{tabular}




\section{Appendix Table. Plant species that occur in marshes and forested wetlands in coastal Louisiana.}

[CC, Cofficient of Conservatism score (0-10) assigned by the coastal Louisiana vegetation expert panel; $\mathrm{N}$, species that are native to the contiguous 48 States of the United States; I, species that are introduced; A, annual; P, perennial; B, biennial, following the U.S. Department of Agriculture's PLANTS Database (USDA, NRCS, 2008); †CC, score when the given species occurs in fresh and intermediate marshes; ¥CC, score when the given species occurs in brackish and saline marshes]

\begin{tabular}{llllll}
\hline \multicolumn{1}{c}{ Scientific name } & CC & Origin & Duration & Form & Family \\
\hline Eleocharis equisetoides (Ell.) Torr. & 7 & $\mathrm{~N}$ & $\mathrm{P}$ & Graminoid & Cyperaceae \\
Eleocharis fallax Weatherby & 5 & $\mathrm{~N}$ & $\mathrm{P}$ & Graminoid & Cyperaceae \\
Eleocharis flavescens (Poir.) Urban & 6 & $\mathrm{~N}$ & $\mathrm{P}$ & Graminoid & Cyperaceae \\
Eleocharis macrostachya Britt. & 7 & $\mathrm{~N}$ & $\mathrm{P}$ & Graminoid & Cyperaceae \\
Eleocharis microcarpa Torr. & 5 & $\mathrm{~N}$ & $\mathrm{~A}$ & Graminoid & Cyperaceae \\
Eleocharis montana (Kunth) Roemer \& J.A. Schultes & 5 & $\mathrm{~N}$ & $\mathrm{P}$ & Graminoid & Cyperaceae \\
Eleocharis montevidensis Kunth & 5 & $\mathrm{~N}$ & $\mathrm{P}$ & Graminoid & Cyperaceae \\
Eleocharis obtusa (Willd.) J.A. Schultes & 3 & $\mathrm{~N}$ & $\mathrm{~A}$ & Graminoid & Cyperaceae \\
Eleocharis olivacea Torr. & 6 & $\mathrm{~N}$ & $\mathrm{P}$ & Graminoid & Cyperaceae \\
Eleocharis palustris (L.) Roemer \& J.A. Schultes & 5 & $\mathrm{~N}$ & $\mathrm{P}$ & Graminoid & Cyperaceae \\
Eleocharis parvula (Roemer \& J.A. Schultes) Link ex Bluff, Nees \& Schauer & 3 & $\mathrm{~N}$ & $\mathrm{~A}$ & Graminoid & Cyperaceae \\
Eleocharis quadrangulata (Michx.) Roemer \& J.A. Schultes & 7 & $\mathrm{~N}$ & $\mathrm{P}$ & Graminoid & Cyperaceae \\
Eleocharis rostellata (Torr.) Torr. & 6 & $\mathrm{~N}$ & $\mathrm{P}$ & Graminoid & Cyperaceae \\
Eleocharis tortilis (Link) J.A. Schultes & 4 & $\mathrm{~N}$ & $\mathrm{P}$ & Graminoid & Cyperaceae \\
Eleocharis tuberculosa (Michx.) Roemer \& J.A. Schultes & 4 & $\mathrm{~N}$ & $\mathrm{P}$ & Graminoid & Cyperaceae \\
Eleocharis vivipara Link & 3 & $\mathrm{~N}$ & $\mathrm{~A}$ & Graminoid & Cyperaceae \\
Equisetum L. & 3 & & & Equisetaceae \\
Equisetum hyemale L. & 3 & $\mathrm{~N}$ & $\mathrm{P}$ & Herb & Equisetaceae \\
Eragrostis hypnoides (Lam.) B.S.P. & 5 & $\mathrm{~N}$ & $\mathrm{~A}$ & Graminoid & Poaceae \\
Eragrostis japonica (Thunb.) Trin. & 0 & $\mathrm{I}$ & $\mathrm{A}$ & Graminoid & Poaceae
\end{tabular}




\section{Appendix Table. Plant species that occur in marshes and forested wetlands in coastal Louisiana.}

[CC, Cofficient of Conservatism score (0-10) assigned by the coastal Louisiana vegetation expert panel; $\mathrm{N}$, species that are native to the contiguous 48 States of the United States; I, species that are introduced; A, annual; P, perennial; B, biennial, following the U.S. Department of Agriculture's PLANTS Database (USDA, NRCS, 2008); †CC, score when the given species occurs in fresh and intermediate marshes; ¥CC, score when the given species occurs in brackish and saline marshes]

\begin{tabular}{|c|c|c|c|c|c|}
\hline Scientific name & $\mathrm{CC}$ & Origin & Duration & Form & Family \\
\hline Erechtites Raf. & 3 & & & & Asteraceae \\
\hline Erechtites hieraciifolia (L.) Raf. ex DC. & 3 & $\mathrm{~N}$ & A & Herb & Asteraceae \\
\hline Eriochloa Kunth & 2 & & & & Poaceae \\
\hline Eriochloa contracta A.S. Hitchc. & 2 & $\mathrm{~N}$ & A & Graminoid & Poaceae \\
\hline Eryngium L. & 3 & & & & Apiaceae \\
\hline Eryngium prostratum Nutt. ex DC. & 3 & $\mathrm{~N}$ & $\mathrm{P}$ & Herb & Apiaceae \\
\hline Eupatorium L. & 3 & & & & Asteraceae \\
\hline Eupatorium capillifolium (Lam.) Small & 1 & $\mathrm{~N}$ & $\mathrm{P}$ & Herb & Asteraceae \\
\hline Eupatorium compositifolium Walt. & 2 & $\mathrm{~N}$ & $\mathrm{P}$ & Herb & Asteraceae \\
\hline Eupatorium perfoliatum L. & 4 & $\mathrm{~N}$ & $\mathrm{P}$ & Herb & Asteraceae \\
\hline Eupatorium pilosum Walt. & 3 & $\mathrm{~N}$ & $\mathrm{P}$ & Herb & Asteraceae \\
\hline Eupatorium purpureum L. & 3 & $\mathrm{~N}$ & $\mathrm{P}$ & Herb & Asteraceae \\
\hline Eupatorium serotinum Michx. & 3 & $\mathrm{~N}$ & $\mathrm{P}$ & Herb & Asteraceae \\
\hline Eustoma Salisb. ex G. Don & 7 & & & & Gentianaceae \\
\hline Eustoma exaltatum (L.) Salisb. ex G. Don & 7 & $\mathrm{~N}$ & A & Herb & Gentianaceae \\
\hline Euthamia Nutt. ex Cass. & 5 & & & & Asteraceae \\
\hline Euthamia leptocephala (Torr. \& Gray) Greene & 5 & $\mathrm{~N}$ & $\mathrm{P}$ & Herb & Asteraceae \\
\hline Fimbristylis annua (All.) Roemer \& J.A. Schultes & 3 & $\mathrm{~N}$ & A & Graminoid & Cyperaceae \\
\hline Fimbristylis caroliniana (Lam.) Fern. & 5 & $\mathrm{~N}$ & $\mathrm{P}$ & Graminoid & Cyperaceae \\
\hline Fimbristylis castanea (Michx.) Vahl & 6 & $\mathrm{~N}$ & $\mathrm{P}$ & Graminoid & Cyperaceae \\
\hline
\end{tabular}




\section{Appendix Table. Plant species that occur in marshes and forested wetlands in coastal Louisiana.}

[CC, Cofficient of Conservatism score (0-10) assigned by the coastal Louisiana vegetation expert panel; $\mathrm{N}$, species that are native to the contiguous 48 States of the United States; I, species that are introduced; A, annual; P, perennial; B, biennial, following the U.S. Department of Agriculture's PLANTS Database (USDA, NRCS, 2008); †CC, score when the given species occurs in fresh and intermediate marshes; ¥CC, score when the given species occurs in brackish and saline marshes]

\begin{tabular}{lccccc}
\hline \multicolumn{1}{c}{ Scientific name } & CC & Origin & Duration & Form & Family \\
\hline Fimbristylis dichotoma (L.) Vahl & 3 & $\mathrm{~N}$ & $\mathrm{~A}$ & Graminoid & Cyperaceae \\
Fimbristylis miliacea (L.) Vahl & 0 & $\mathrm{~N}$ & $\mathrm{~A}$ & Graminoid & Cyperaceae \\
Fimbristylis tomentosa Vahl & 3 & $\mathrm{~N}$ & $\mathrm{~A}$ & Graminoid & Cyperaceae \\
Forestiera Poir. & 5 & & & & Oleaceae \\
Forestiera acuminata (Michx.) Poir. & 5 & $\mathrm{~N}$ & $\mathrm{P}$ & Shrub & Oleaceae \\
Frangula P. Mill. & 6 & & & & Rhamnaceae \\
Frangula caroliniana (Walt.) Gray & 6 & $\mathrm{~N}$ & $\mathrm{P}$ & Tree & Rhamnaceae \\
Fraxinus L. & 7 & & & & Oleaceae \\
Fraxinus caroliniana P. Mill. & 7 & $\mathrm{~N}$ & $\mathrm{P}$ & Tree & Oleaceae \\
Fraxinus pennsylvanica Marsh. & 7 & $\mathrm{~N}$ & $\mathrm{P}$ & Tree & Oleaceae \\
Fraxinus profunda (Bush) Bush & 7 & $\mathrm{~N}$ & $\mathrm{P}$ & Tree & Oleaceae \\
Fuirena Rottb. & 4 & & & & Cyperaceae \\
Fuirena breviseta (Coville) Coville & 5 & $\mathrm{~N}$ & $\mathrm{P}$ & Graminoid & Cyperaceae \\
Fuirena pumila (Torr.) Spreng. & 3 & $\mathrm{~N}$ & $\mathrm{~A}$ & Graminoid & Cyperaceae \\
Fuirena squarrosa Michx. & 4 & $\mathrm{~N}$ & $\mathrm{P}$ & Graminoid & Cyperaceae \\
Gaillardia Foug. & 4 & & & Asteraceae \\
Gaillardia pulchella Foug. & 4 & $\mathrm{~N}$ & $\mathrm{~A}, \mathrm{~B}, \mathrm{P}$ & Subshrub & Asteraceae \\
Galium L. & 2 & & & $\mathrm{~N}$ & Rubiaceae \\
Galium obtusum Bigelow & 2 & $\mathrm{~N}$ & Herb \\
Galium tinctorium L. & 2 & $\mathrm{~N}$ & $\mathrm{P}$ & Herb & Rubiaceae
\end{tabular}




\section{Appendix Table. Plant species that occur in marshes and forested wetlands in coastal Louisiana.}

[CC, Cofficient of Conservatism score (0-10) assigned by the coastal Louisiana vegetation expert panel; $\mathrm{N}$, species that are native to the contiguous 48 States of the United States; I, species that are introduced; A, annual; P, perennial; B, biennial, following the U.S. Department of Agriculture's PLANTS Database (USDA, NRCS, 2008); †CC, score when the given species occurs in fresh and intermediate marshes; ¥CC, score when the given species occurs in brackish and saline marshes]

\begin{tabular}{|c|c|c|c|c|c|}
\hline Scientific name & $\mathrm{CC}$ & Origin & Duration & Form & Family \\
\hline Galium trifidum L. & 2 & $\mathrm{~N}$ & $\mathrm{P}$ & Herb & Rubiaceae \\
\hline Gleditsia L. & 6 & & & & Fabaceae \\
\hline Gleditsia aquatica Marsh. & 7 & $\mathrm{~N}$ & $\mathrm{P}$ & Tree & Fabaceae \\
\hline Gleditsia triacanthos L. & 6 & $\mathrm{~N}$ & $\mathrm{P}$ & Tree & Fabaceae \\
\hline Gratiola L. & 4 & & & & Scrophulariaceae \\
\hline Gratiola brevifolia Raf. & 5 & $\mathrm{~N}$ & A & Herb & Scrophulariaceae \\
\hline Gratiola neglecta Torr. & 4 & $\mathrm{~N}$ & $\mathrm{~A}$ & Herb & Scrophulariaceae \\
\hline Gratiola virginiana L. & 4 & $\mathrm{~N}$ & A & Herb & Scrophulariaceae \\
\hline Habenaria Willd. & 5 & & & & Orchidaceae \\
\hline Habenaria repens Nutt. & 5 & $\mathrm{~N}$ & $\mathrm{P}$ & Herb & Orchidaceae \\
\hline Helenium L. & 2 & & & & Asteraceae \\
\hline Helenium amarum (Raf.) H. Rock & 2 & $\mathrm{~N}$ & A & Herb & Asteraceae \\
\hline Helenium autumnale L. & 3 & $\mathrm{~N}$ & $\mathrm{P}$ & Herb & Asteraceae \\
\hline Helianthus L. & 6 & & & & Asteraceae \\
\hline Helianthus angustifolius L. & 6 & $\mathrm{~N}$ & $\mathrm{P}$ & Herb & Asteraceae \\
\hline Heliotropium L. & 3 & & & & Boraginaceae \\
\hline Heliotropium curassavicum L. & 4 & $\mathrm{~N}$ & A & Herb & Boraginaceae \\
\hline Heliotropium procumbens P. Mill. & 3 & $\mathrm{~N}$ & A & Herb & Boraginaceae \\
\hline Heteranthera Ruiz \& Pav. & 3 & & & & Pontederiaceae \\
\hline Heteranthera dubia (Jacq.) MacM. & 3 & $\mathrm{~N}$ & A & Herb & Pontederiaceae \\
\hline
\end{tabular}




\section{Appendix Table. Plant species that occur in marshes and forested wetlands in coastal Louisiana.}

[CC, Cofficient of Conservatism score (0-10) assigned by the coastal Louisiana vegetation expert panel; $\mathrm{N}$, species that are native to the contiguous 48 States of the United States; I, species that are introduced; A, annual; P, perennial; B, biennial, following the U.S. Department of Agriculture's PLANTS Database (USDA, NRCS, 2008); †CC, score when the given species occurs in fresh and intermediate marshes; ¥CC, score when the given species occurs in brackish and saline marshes]

\begin{tabular}{|c|c|c|c|c|c|}
\hline Scientific name & CC & Origin & Duration & Form & Family \\
\hline Heteranthera limosa (Sw.) Willd. & 3 & $\mathrm{~N}$ & A & Herb & Pontederiaceae \\
\hline Heteranthera reniformis Ruiz \& Pavon & 4 & $\mathrm{~N}$ & $\mathrm{P}$ & Herb & Pontederiaceae \\
\hline Hibiscus L. & 6 & & & & Malvaceae \\
\hline Hibiscus grandiflorus Michx. & 6 & $\mathrm{~N}$ & $\mathrm{P}$ & Shrub & Malvaceae \\
\hline Hibiscus laevis All. & 6 & $\mathrm{~N}$ & $\mathrm{P}$ & Herb & Malvaceae \\
\hline Hibiscus lasiocarpos Cav. & 7 & $\mathrm{~N}$ & $\mathrm{P}$ & Herb & Malvaceae \\
\hline Hibiscus moscheutos L. & 7 & $\mathrm{~N}$ & $\mathrm{P}$ & Herb & Malvaceae \\
\hline Hydrocotyle L. & 3 & & & & Apiaceae \\
\hline Hydrocotyle bonariensis Comm. ex Lam. & 4 & $\mathrm{~N}$ & $\mathrm{P}$ & Herb & Apiaceae \\
\hline Hydrocotyle ranunculoides L. f. & 4 & $\mathrm{~N}$ & $\mathrm{P}$ & Herb & Apiaceae \\
\hline Hydrocotyle umbellata L. & 3 & $\mathrm{~N}$ & $\mathrm{P}$ & Herb & Apiaceae \\
\hline Hydrocotyle verticillata Thunb. & 3 & $\mathrm{~N}$ & $\mathrm{P}$ & Herb & Apiaceae \\
\hline Hydrolea L. & 5 & & & & Hydrophyllaceae \\
\hline Hydrolea ovata Nutt. ex Choisy & 5 & $\mathrm{~N}$ & $\mathrm{P}$ & Herb & Hydrophyllaceae \\
\hline Hydrolea uniflora Raf. & 5 & $\mathrm{~N}$ & $\mathrm{P}$ & Herb & Hydrophyllaceae \\
\hline Hygrophila R. Br. & 5 & & & & Acanthaceae \\
\hline Hygrophila lacustris (Schlecht. \& Cham.) Nees & 5 & $\mathrm{~N}$ & $\mathrm{P}$ & Herb & Acanthaceae \\
\hline Hymenocallis Salisb. & 7 & & & & Liliaceae \\
\hline Hymenocallis caroliniana (L.) Herbert & 7 & $\mathrm{~N}$ & $\mathrm{P}$ & Herb & Liliaceae \\
\hline Hymenocallis liriosme (Raf.) Shinners & 7 & $\mathrm{~N}$ & $\mathrm{P}$ & Herb & Liliaceae \\
\hline
\end{tabular}




\section{Appendix Table. Plant species that occur in marshes and forested wetlands in coastal Louisiana.}

[CC, Cofficient of Conservatism score (0-10) assigned by the coastal Louisiana vegetation expert panel; $\mathrm{N}$, species that are native to the contiguous 48 States of the United States; I, species that are introduced; A, annual; P, perennial; B, biennial, following the U.S. Department of Agriculture's PLANTS Database (USDA, NRCS, 2008); †CC, score when the given species occurs in fresh and intermediate marshes; $¥ C C$, score when the given species occurs in brackish and saline marshes]

\begin{tabular}{llllll}
\hline \multicolumn{1}{c}{ Scientific name } & CC & Origin & Duration & Form & Family \\
\hline Hypericum crux-andreae (L.) Crantz & 6 & $\mathrm{~N}$ & $\mathrm{P}$ & Subshrub & Clusiaceae \\
Hypericum drummondii (Grev. \& Hook.) Torr. \& Gray & 6 & $\mathrm{~N}$ & $\mathrm{~A}$ & Herb & Clusiaceae \\
Hypericum fasciculatum Lam. & 7 & $\mathrm{~N}$ & $\mathrm{P}$ & Shrub & Clusiaceae \\
Hypericum hypericoides (L.) Crantz & 5 & $\mathrm{~N}$ & $\mathrm{P}$ & Subshrub & Clusiaceae \\
Hypericum mutilum L. & 4 & $\mathrm{~N}$ & $\mathrm{~A}$ & Herb & Clusiaceae \\
Hypericum perforatum L. & 0 & $\mathrm{I}$ & $\mathrm{P}$ & Herb & Clusiaceae \\
Hyptis Jacq. & 5 & & & & Lamiaceae \\
Hyptis alata (Raf.) Shinners & 5 & $\mathrm{~N}$ & $\mathrm{P}$ & Herb & Lamiaceae \\
Ilex L. & 7 & & & & Aquifoliaceae \\
Ilex ambigua (Michx.) Torr. & 6 & $\mathrm{~N}$ & $\mathrm{P}$ & Shrub & Aquifoliaceae \\
Ilex cassine L. & 7 & $\mathrm{~N}$ & $\mathrm{P}$ & Shrub & Aquifoliaceae \\
Ilex coriacea (Pursh) Chapman & 7 & $\mathrm{~N}$ & $\mathrm{P}$ & Shrub & Aquifoliaceae \\
Ilex decidua Walt. & 7 & $\mathrm{~N}$ & $\mathrm{P}$ & Shrub & Aquifoliaceae \\
Ilex glabra (L.) Gray & 7 & $\mathrm{~N}$ & $\mathrm{P}$ & Shrub & Aquifoliaceae \\
Ilex myrtifolia Walt. & 7 & $\mathrm{~N}$ & $\mathrm{P}$ & Shrub & Aquifoliaceae \\
Ilex verticillata (L.) Gray & 6 & $\mathrm{~N}$ & $\mathrm{P}$ & Shrub & Aquifoliaceae \\
Ilex vomitoria Ait. & 7 & $\mathrm{~N}$ & $\mathrm{P}$ & Shrub & Aquifoliaceae \\
Ipomoea coccinea L. & 0 & $\mathrm{I}$ & $\mathrm{A}$ & Vine & Convolvulaceae \\
Ipomoea imperati (Vahl) Griseb. & 7 & $\mathrm{~N}$ & $\mathrm{P}$ & Vine & Convolvulaceae \\
Ipomoea pes-caprae (L.) R. Br. & 7 & $\mathrm{~N}$ & $\mathrm{P}$ & Vine & Convolvulaceae
\end{tabular}




\section{Appendix Table. Plant species that occur in marshes and forested wetlands in coastal Louisiana.}

[CC, Cofficient of Conservatism score (0-10) assigned by the coastal Louisiana vegetation expert panel; $\mathrm{N}$, species that are native to the contiguous 48 States of the United States; I, species that are introduced; A, annual; P, perennial; B, biennial, following the U.S. Department of Agriculture's PLANTS Database (USDA, NRCS, 2008); †CC, score when the given species occurs in fresh and intermediate marshes; ¥CC, score when the given species occurs in brackish and saline marshes]

\begin{tabular}{|c|c|c|c|c|c|}
\hline Scientific name & $\mathrm{CC}$ & Origin & Duration & Form & Family \\
\hline Ipomoea sagittata Poir. & 8 & $\mathrm{~N}$ & $\mathrm{P}$ & Vine & Convolvulaceae \\
\hline Iresine P. Br. & 6 & & & & Amaranthaceae \\
\hline Iresine rhizomatosa Standl. & 6 & $\mathrm{~N}$ & $\mathrm{P}$ & Herb & Amaranthaceae \\
\hline Iris fulva Ker-Gawl. & 7 & $\mathrm{~N}$ & $\mathrm{P}$ & Herb & Iridaceae \\
\hline Iris giganticaerulea Small & 7 & $\mathrm{~N}$ & $\mathrm{P}$ & Herb & Iridaceae \\
\hline Iris pseudacorus L. & 0 & I & $\mathrm{P}$ & Herb & Iridaceae \\
\hline Iris virginica $\mathrm{L}$. & 7 & $\mathrm{~N}$ & $\mathrm{P}$ & Herb & Iridaceae \\
\hline Isolepis R. Br. & 2 & & & & Cyperaceae \\
\hline Isolepis carinata Hook. \& Arn. ex Torr. & 2 & $\mathrm{~N}$ & A & Graminoid & Сyperaceae \\
\hline Itea $\mathrm{L}$. & 7 & & & & Grossulariaceae \\
\hline Itea virginica $\mathrm{L}$. & 7 & $\mathrm{~N}$ & $\mathrm{P}$ & Shrub & Grossulariaceae \\
\hline Iva angustifolia Nutt. ex DC. & 2 & $\mathrm{~N}$ & A & Herb & Asteraceae \\
\hline Iva annua $\mathrm{L}$. & 2 & $\mathrm{~N}$ & A & Shrub & Asteraceae \\
\hline Iva frutescens L. & 4 & $\mathrm{~N}$ & $\mathrm{P}$ & Shrub & Asteraceae \\
\hline Iva imbricata Walt. & 4 & $\mathrm{~N}$ & $\mathrm{P}$ & Subshrub & Asteraceae \\
\hline Juncus acuminatus Michx. & 5 & $\mathrm{~N}$ & $\mathrm{P}$ & Graminoid & Juncaceae \\
\hline Juncus bufonius L. & 3 & $\mathrm{~N}$ & A & Graminoid & Juncaceae \\
\hline Juncus canadensis J. Gay ex Laharpe & 6 & $\mathrm{~N}$ & $\mathrm{P}$ & Graminoid & Juncaceae \\
\hline
\end{tabular}




\section{Appendix Table. Plant species that occur in marshes and forested wetlands in coastal Louisiana.}

[CC, Cofficient of Conservatism score (0-10) assigned by the coastal Louisiana vegetation expert panel; $\mathrm{N}$, species that are native to the contiguous 48 States of the United States; I, species that are introduced; A, annual; P, perennial; B, biennial, following the U.S. Department of Agriculture's PLANTS Database (USDA, NRCS, 2008); †CC, score when the given species occurs in fresh and intermediate marshes; ¥CC, score when the given species occurs in brackish and saline marshes]

\begin{tabular}{|c|c|c|c|c|c|}
\hline Scientific name & $\mathrm{CC}$ & Origin & Duration & Form & Family \\
\hline Juncus coriaceus Mackenzie & 5 & $\mathrm{~N}$ & $\mathrm{P}$ & Graminoid & Juncaceae \\
\hline Juncus dichotomus Ell. & 5 & $\mathrm{~N}$ & $\mathrm{P}$ & Graminoid & Juncaceae \\
\hline Juncus diffusissimus Buckl. & 4 & $\mathrm{~N}$ & $\mathrm{P}$ & Graminoid & Juncaceae \\
\hline Juncus effusus L. & 8 & $\mathrm{~N}$ & $\mathrm{P}$ & Graminoid & Juncaceae \\
\hline Juncus interior Wieg. & 3 & $\mathrm{~N}$ & $\mathrm{P}$ & Graminoid & Juncaceae \\
\hline Juncus marginatus Rostk. & 5 & $\mathrm{~N}$ & $\mathrm{P}$ & Graminoid & Juncaceae \\
\hline Juncus nodatus Coville & 5 & $\mathrm{~N}$ & $\mathrm{P}$ & Graminoid & Juncaceae \\
\hline Juncus repens Michx. & 5 & $\mathrm{~N}$ & A & Graminoid & Juncaceae \\
\hline Juncus roemerianus Scheele & 9 & $\mathrm{~N}$ & $\mathrm{P}$ & Graminoid & Juncaceae \\
\hline Juncus scirpoides Lam. & 5 & $\mathrm{~N}$ & $\mathrm{P}$ & Graminoid & Juncaceae \\
\hline Juncus tenuis Willd. & 3 & $\mathrm{~N}$ & $\mathrm{P}$ & Graminoid & Juncaceae \\
\hline Juncus validus Coville & 5 & $\mathrm{~N}$ & $\mathrm{P}$ & Graminoid & Juncaceae \\
\hline Justicia L. & 5 & & & & Acanthaceae \\
\hline Justicia americana (L.) Vahl & 6 & $\mathrm{~N}$ & $\mathrm{P}$ & Herb & Acanthaceae \\
\hline Justicia ovata (Walt.) Lindau & 5 & $\mathrm{~N}$ & $\mathrm{P}$ & Herb & Acanthaceae \\
\hline Kosteletzkya K. Presl & 7 & & & & Malvaceae \\
\hline Kosteletzkya virginica (L.) K. Presl ex Gray & 7 & $\mathrm{~N}$ & $\mathrm{P}$ & Herb & Malvaceae \\
\hline Kyllinga Rottb. & 2 & & & & Cyperaceae \\
\hline Kyllinga brevifolia Rottb. & 2 & $\mathrm{~N}$ & $\mathrm{P}$ & Graminoid & Cyperaceae \\
\hline Kyllinga pumila Michx. & 2 & $\mathrm{~N}$ & A,P & Graminoid & Cyperaceae \\
\hline
\end{tabular}




\section{Appendix Table. Plant species that occur in marshes and forested wetlands in coastal Louisiana.}

[CC, Cofficient of Conservatism score (0-10) assigned by the coastal Louisiana vegetation expert panel; $\mathrm{N}$, species that are native to the contiguous 48 States of the United States; I, species that are introduced; A, annual; P, perennial; B, biennial, following the U.S. Department of Agriculture's PLANTS Database (USDA, NRCS, 2008); †CC, score when the given species occurs in fresh and intermediate marshes; ¥CC, score when the given species occurs in brackish and saline marshes]

\begin{tabular}{|c|c|c|c|c|c|}
\hline Scientific name & CC & Origin & Duration & Form & Family \\
\hline Lachnanthes Ell. & 7 & & & & Haemodoraceae \\
\hline Lachnanthes caroliana (Lam.) Dandy & 7 & $\mathrm{~N}$ & $\mathrm{P}$ & Herb & Haemodoraceae \\
\hline Leersia Sw. & 7 & & & & Poaceae \\
\hline Leersia hexandra Sw. & 7 & $\mathrm{~N}$ & $\mathrm{P}$ & Graminoid & Poaceae \\
\hline Leersia oryzoides (L.) Sw. & 7 & $\mathrm{~N}$ & $\mathrm{P}$ & Graminoid & Poaceae \\
\hline Leersia virginica Willd. & 7 & $\mathrm{~N}$ & $\mathrm{P}$ & Graminoid & Poaceae \\
\hline Lepidium L. & 2 & & & & Brassicaceae \\
\hline Lepidium virginicum L. & 2 & $\mathrm{~N}$ & A & Herb & Brassicaceae \\
\hline Leptochloa Beauv. & 2 & & & & Poaceae \\
\hline Leptochloa fusca (L.) Kunth & 2 & $\mathrm{~N}$ & A & Graminoid & Poaceae \\
\hline Leptochloa panicea (Retz.) Ohwi & 2 & $\mathrm{~N}$ & A & Graminoid & Poaceae \\
\hline Lespedeza Michx. & 6 & & & & Fabaceae \\
\hline Lespedeza stuevei Nutt. & 6 & $\mathrm{~N}$ & $\mathrm{P}$ & Herb & Fabaceae \\
\hline Leucospora Nutt. & 2 & & & & Scrophulariaceae \\
\hline Leucospora multifida (Michx.) Nutt. & 2 & $\mathrm{~N}$ & A & Herb & Scrophulariaceae \\
\hline Lilaeopsis Greene & 6 & & & & Apiaceae \\
\hline Lilaeopsis carolinensis Coult. \& Rose & 6 & $\mathrm{~N}$ & $\mathrm{P}$ & Herb & Apiaceae \\
\hline Lilaeopsis chinensis (L.) Kuntze & 6 & $\mathrm{~N}$ & $\mathrm{P}$ & Herb & Apiaceae \\
\hline Limnobium L.C. Rich. & 5 & & & & Hydrocharitaceae \\
\hline Limnobium spongia (Bosc) L.C. Rich. ex Steud. & 5 & $\mathrm{~N}$ & $\mathrm{P}$ & Herb & Hydrocharitaceae \\
\hline
\end{tabular}




\section{Appendix Table. Plant species that occur in marshes and forested wetlands in coastal Louisiana.}

[CC, Cofficient of Conservatism score (0-10) assigned by the coastal Louisiana vegetation expert panel; $\mathrm{N}$, species that are native to the contiguous 48 States of the United States; I, species that are introduced; A, annual; P, perennial; B, biennial, following the U.S. Department of Agriculture's PLANTS Database (USDA, NRCS, 2008); †CC, score when the given species occurs in fresh and intermediate marshes; ¥CC, score when the given species occurs in brackish and saline marshes]

\begin{tabular}{|c|c|c|c|c|c|}
\hline Scientific name & $\mathrm{CC}$ & Origin & Duration & Form & Family \\
\hline Limnosciadium Mathias \& Constance & 2 & & & & Apiaceae \\
\hline Limnosciadium pinnatum (DC.) Mathias \& Constance & 3 & $\mathrm{~N}$ & A & Herb & Apiaceae \\
\hline Limnosciadium pumilum (Engelm. \& Gray) Mathias \& Constance & 2 & $\mathrm{~N}$ & A & Herb & Apiaceae \\
\hline Limonium P. Mill. & 7 & & & & Plumbaginaceae \\
\hline Limonium carolinianum (Walt.) Britt. & 7 & $\mathrm{~N}$ & $\mathrm{P}$ & Herb & Plumbaginaceae \\
\hline Lindernia All. & 3 & & & & Scrophulariaceae \\
\hline Lindernia dubia (L.) Pennell & 3 & $\mathrm{~N}$ & A & Herb & Scrophulariaceae \\
\hline Linum L. & 3 & & & & Linaceae \\
\hline Linum medium (Planch.) Britt. & 3 & $\mathrm{~N}$ & A & Herb & Linaceae \\
\hline Liquidambar L. & 6 & & & & Hamamelidaceae \\
\hline Liquidambar styraciflua L. & 6 & $\mathrm{~N}$ & $\mathrm{P}$ & Tree & Hamamelidaceae \\
\hline Lobelia L. & 8 & & & & Campanulaceae \\
\hline Lobelia cardinalis L. & 8 & $\mathrm{~N}$ & $\mathrm{P}$ & Herb & Campanulaceae \\
\hline Ludwigia L. & 4 & & & & Onagraceae \\
\hline Ludwigia alata Ell. & 4 & $\mathrm{~N}$ & $\mathrm{P}$ & Herb & Onagraceae \\
\hline Ludwigia decurrens Walt. & 4 & $\mathrm{~N}$ & A & Herb & Onagraceae \\
\hline Ludwigia glandulosa Walt. & 4 & $\mathrm{~N}$ & $\mathrm{P}$ & Herb & Onagraceae \\
\hline Ludwigia grandiflora (Michx.) Greuter \& Burdet & 4 & $\mathrm{~N}$ & $\mathrm{P}$ & Herb & Onagraceae \\
\hline Ludwigia leptocarpa (Nutt.) Hara & 4 & $\mathrm{~N}$ & A & Herb & Onagraceae \\
\hline Ludwigia linearis Walt. & 5 & $\mathrm{~N}$ & $\mathrm{P}$ & Herb & Onagraceae \\
\hline
\end{tabular}




\section{Appendix Table. Plant species that occur in marshes and forested wetlands in coastal Louisiana.}

[CC, Cofficient of Conservatism score (0-10) assigned by the coastal Louisiana vegetation expert panel; $\mathrm{N}$, species that are native to the contiguous 48 States of the United States; I, species that are introduced; A, annual; P, perennial; B, biennial, following the U.S. Department of Agriculture's PLANTS Database (USDA, NRCS, 2008); †CC, score when the given species occurs in fresh and intermediate marshes; ¥CC, score when the given species occurs in brackish and saline marshes]

\begin{tabular}{llllll}
\hline \multicolumn{1}{c}{ Scientific name } & CC & Origin & Duration & Form & Family \\
\hline Ludwigia microcarpa Michx. & 5 & $\mathrm{~N}$ & $\mathrm{P}$ & Herb & Onagraceae \\
Ludwigia octovalvis (Jacq.) Raven & 3 & $\mathrm{~N}$ & $\mathrm{P}$ & Herb & Onagraceae \\
Ludwigia palustris (L.) Ell. & 4 & $\mathrm{~N}$ & $\mathrm{P}$ & Herb & Onagraceae \\
Ludwigia peploides (Kunth) Raven & 4 & $\mathrm{~N}$ & $\mathrm{P}$ & Herb & Onagraceae \\
Ludwigia repens J.R. Forst. & 5 & $\mathrm{~N}$ & $\mathrm{P}$ & Herb & Onagraceae \\
Ludwigia sphaerocarpa Ell. & 5 & $\mathrm{~N}$ & $\mathrm{P}$ & Herb & Onagraceae \\
Luziola fluitans (Michx.) Terrell \& H. Robins. & 5 & $\mathrm{~N}$ & $\mathrm{P}$ & Graminoid & Poaceae \\
Luziola peruviana Juss. ex J.F. Gmel. & 0 & $\mathrm{I}$ & $\mathrm{P}$ & Graminoid & Poaceae \\
Lycium L. & 6 & & & & Solanaceae \\
Lycium carolinianum Walt. & 6 & $\mathrm{~N}$ & $\mathrm{P}$ & Shrub & Solanaceae \\
Lycopus L. & 4 & & & & Lamiaceae \\
Lycopus americanus Muhl. ex W. Bart. & 4 & $\mathrm{~N}$ & $\mathrm{P}$ & Herb & Lamiaceae \\
Lycopus rubellus Moench & 4 & $\mathrm{~N}$ & $\mathrm{P}$ & Herb & Lamiaceae \\
Lycopus virginicus L. & 5 & $\mathrm{~N}$ & $\mathrm{P}$ & Herb & Lamiaceae \\
Lygodium Sw. & 0 & & & Lygodiaceae \\
Lygodium japonicum (Thunb. ex Murr.) Sw. & 0 & $\mathrm{I}$ & $\mathrm{P}$ & Vine & Lygodiaceae \\
Lythrum L. & 5 & & & Lythraceae \\
Lythrum lineare L. & 5 & $\mathrm{~N}$ & $\mathrm{P}$ & Herb & Lythraceae \\
Magnolia L. & 7 & & & Magnoliaceae \\
Magnolia grandiflora L. & 7 & $\mathrm{~N}$ & $\mathrm{P}$ & Tree & Magnoliaceae
\end{tabular}




\section{Appendix Table. Plant species that occur in marshes and forested wetlands in coastal Louisiana.}

[CC, Cofficient of Conservatism score (0-10) assigned by the coastal Louisiana vegetation expert panel; $\mathrm{N}$, species that are native to the contiguous 48 States of the United States; I, species that are introduced; A, annual; P, perennial; B, biennial, following the U.S. Department of Agriculture's PLANTS Database (USDA, NRCS, 2008); †CC, score when the given species occurs in fresh and intermediate marshes; ¥CC, score when the given species occurs in brackish and saline marshes]

\begin{tabular}{|c|c|c|c|c|c|}
\hline Scientific name & $\mathrm{CC}$ & Origin & Duration & Form & Family \\
\hline Magnolia virginiana $\mathrm{L}$. & 7 & $\mathrm{~N}$ & $\mathrm{P}$ & Tree & Magnoliaceae \\
\hline Mecardonia Ruiz \& Pav. & 4 & & & & Scrophulariaceae \\
\hline Melia L. & 0 & & & & Meliaceae \\
\hline Melia azedarach L. & 0 & I & $\mathrm{P}$ & Tree & Meliaceae \\
\hline Melochia L. & 0 & & & & Sterculiaceae \\
\hline Melochia corchorifolia L. & 0 & I & A & Herb & Sterculiaceae \\
\hline Micranthemum Michx. & 4 & & & & Scrophulariaceae \\
\hline Micranthemum umbrosum (J.F. Gmel.) Blake & 4 & $\mathrm{~N}$ & A & Herb & Scrophulariaceae \\
\hline Mikania Willd. & 4 & & & & Asteraceae \\
\hline Mikania cordifolia (L. f.) Willd. & 4 & $\mathrm{~N}$ & $\mathrm{P}$ & Vine & Asteraceae \\
\hline Mikania scandens (L.) Willd. & 3 & $\mathrm{~N}$ & $\mathrm{P}$ & Vine & Asteraceae \\
\hline Mimulus alatus Ait. & 5 & $\mathrm{~N}$ & $\mathrm{P}$ & Herb & Scrophulariaceae \\
\hline Mitreola L. & 5 & & & & Loganiaceae \\
\hline Mitreola petiolata (J.F. Gmel.) Torr. \& Gray & 5 & $\mathrm{~N}$ & A & Herb & Loganiaceae \\
\hline Mitreola sessilifolia (J.F. Gmel.) G. Don & 5 & $\mathrm{~N}$ & A & Herb & Loganiaceae \\
\hline Monanthochloe Engelm. & 8 & & & & Poaceae \\
\hline Monanthochloe littoralis Engelm. & 8 & $\mathrm{~N}$ & $\mathrm{P}$ & Graminoid & Poaceae \\
\hline Morella Lour. & 6 & & & & Myricaceae \\
\hline
\end{tabular}




\section{Appendix Table. Plant species that occur in marshes and forested wetlands in coastal Louisiana.}

[CC, Cofficient of Conservatism score (0-10) assigned by the coastal Louisiana vegetation expert panel; $\mathrm{N}$, species that are native to the contiguous 48 States of the United States; I, species that are introduced; A, annual; P, perennial; B, biennial, following the U.S. Department of Agriculture's PLANTS Database (USDA, NRCS, 2008); †CC, score when the given species occurs in fresh and intermediate marshes; ¥CC, score when the given species occurs in brackish and saline marshes]

\begin{tabular}{|c|c|c|c|c|c|}
\hline Scientific name & CC & Origin & Duration & Form & Family \\
\hline Morella caroliniensis (P. Mill.) Small & 6 & $\mathrm{~N}$ & $\mathrm{P}$ & Shrub & Myricaceae \\
\hline Morella cerifera (L.) Small & 6 & $\mathrm{~N}$ & $\mathrm{P}$ & Shrub & Myricaceae \\
\hline Nelumbo Adans. & 6 & & & & Nelumbonaceae \\
\hline Nelumbo lutea Willd. & 6 & $\mathrm{~N}$ & $\mathrm{P}$ & Herb & Nelumbonaceae \\
\hline Nuphar Sm. & 6 & & & & Nymphaeaceae \\
\hline Nuphar lutea (L.) Sm. & 6 & $\mathrm{~N}$ & $\mathrm{P}$ & Herb & Nymphaeaceae \\
\hline Nymphaea L. & 6 & & & & Nymphaeaceae \\
\hline Nymphaea elegans Hook. & 6 & $\mathrm{~N}$ & $\mathrm{P}$ & Herb & Nymphaeaceae \\
\hline Nymphaea mexicana Zucc. & 6 & $\mathrm{~N}$ & $\mathrm{P}$ & Herb & Nymphaeaceae \\
\hline Nymphaea odorata Ait. & 7 & $\mathrm{~N}$ & $\mathrm{P}$ & Herb & Nymphaeaceae \\
\hline Nymphoides Hill & 7 & & & & Menyanthaceae \\
\hline Nymphoides aquatica (J.F. Gmel.) Kuntze & 7 & $\mathrm{~N}$ & $\mathrm{P}$ & Herb & Menyanthaceae \\
\hline Nymphoides cordata (Ell.) Fern. & 7 & $\mathrm{~N}$ & $\mathrm{P}$ & Herb & Menyanthaceae \\
\hline Nyssa L. & 8 & & & & Cornaceae \\
\hline Nyssa aquatica L. & 9 & $\mathrm{~N}$ & $\mathrm{P}$ & Tree & Cornaceae \\
\hline Nyssa biflora Walt. & 8 & $\mathrm{~N}$ & $\mathrm{P}$ & Tree & Cornaceae \\
\hline Nyssa sylvatica Marsh. & 7 & $\mathrm{~N}$ & $\mathrm{P}$ & Tree & Cornaceae \\
\hline Oldenlandia L. & 3 & & & & Rubiaceae \\
\hline Oldenlandia uniflora L. & 3 & $\mathrm{~N}$ & $\mathrm{~A}$ & Subshrub & Rubiaceae \\
\hline Opuntia P. Mill. & 4 & & & & Cactaceae \\
\hline
\end{tabular}




\section{Appendix Table. Plant species that occur in marshes and forested wetlands in coastal Louisiana.}

[CC, Cofficient of Conservatism score (0-10) assigned by the coastal Louisiana vegetation expert panel; $\mathrm{N}$, species that are native to the contiguous 48 States of the United States; I, species that are introduced; A, annual; P, perennial; B, biennial, following the U.S. Department of Agriculture's PLANTS Database (USDA, NRCS, 2008); †CC, score when the given species occurs in fresh and intermediate marshes; ¥CC, score when the given species occurs in brackish and saline marshes]

\begin{tabular}{|c|c|c|c|c|c|}
\hline Scientific name & $\mathrm{CC}$ & Origin & Duration & Form & Family \\
\hline Opuntia humifusa (Raf.) Raf. & 4 & $\mathrm{~N}$ & $\mathrm{P}$ & Cactus & Cactaceae \\
\hline Orontium L. & 7 & & & & Araceae \\
\hline Orontium aquaticum L. & 7 & $\mathrm{~N}$ & $\mathrm{P}$ & Herb & Araceae \\
\hline Oryza L. & 0 & & & & Poaceae \\
\hline Oryza sativa $\mathrm{L}$. & 0 & I & $\mathrm{P}$ & Graminoid & Poaceae \\
\hline Osmunda L. & 7 & & & & Osmundaceae \\
\hline Osmunda cinnamomea L. & 7 & $\mathrm{~N}$ & $\mathrm{P}$ & Fern & Osmundaceae \\
\hline Osmunda regalis $\mathrm{L}$. & 8 & $\mathrm{~N}$ & $\mathrm{P}$ & Fern & Osmundaceae \\
\hline Ottelia Pers. & 0 & & & & Hydrocharitaceae \\
\hline Ottelia alismoides (L.) Pers. & 0 & I & $\mathrm{P}$ & Herb & Hydrocharitaceae \\
\hline Oxycaryum Nees & 3 & & & & Cyperaceae \\
\hline Oxycaryum cubense (Poepp. \& Kunth) Lye & 3 & $\mathrm{~N}$ & $\mathrm{P}$ & Graminoid & Cyperaceae \\
\hline Packera A. Löve \& D. Löve & 1 & & & & Asteraceae \\
\hline Packera glabella (Poir) C. Jeffrey & 1 & $\mathrm{~N}$ & A & Herb & Asteraceae \\
\hline Panicum amarum Ell. & 7 & $\mathrm{~N}$ & $\mathrm{P}$ & Graminoid & Poaceae \\
\hline Panicum anceps Michx. & 5 & $\mathrm{~N}$ & $\mathrm{P}$ & Graminoid & Poaceae \\
\hline Panicum capillare L. & 2 & $\mathrm{~N}$ & A & Graminoid & Poaceae \\
\hline Panicum dichotomiflorum Michx. & 3 & $\mathrm{~N}$ & A & Graminoid & Poaceae \\
\hline Panicum hemitomon J.A. Schultes & 10 & $\mathrm{~N}$ & $\mathrm{P}$ & Graminoid & Poaceae \\
\hline Panicum repens L. & 3 & $\mathrm{~N}$ & $\mathrm{P}$ & Graminoid & Poaceae \\
\hline
\end{tabular}




\section{Appendix Table. Plant species that occur in marshes and forested wetlands in coastal Louisiana.}

[CC, Cofficient of Conservatism score (0-10) assigned by the coastal Louisiana vegetation expert panel; $\mathrm{N}$, species that are native to the contiguous 48 States of the United States; I, species that are introduced; A, annual; P, perennial; B, biennial, following the U.S. Department of Agriculture's PLANTS Database (USDA, NRCS, 2008); †CC, score when the given species occurs in fresh and intermediate marshes; ¥CC, score when the given species occurs in brackish and saline marshes]

\begin{tabular}{lccccc}
\hline \multicolumn{1}{c}{ Scientific name } & CC & Origin & Duration & Form & Family \\
\hline Panicum rigidulum Bosc ex Nees & 5 & $\mathrm{~N}$ & $\mathrm{P}$ & Graminoid & Poaceae \\
Panicum tenerum Bey. ex Trin. & 5 & $\mathrm{~N}$ & $\mathrm{P}$ & Graminoid & Poaceae \\
Panicum verrucosum Muhl. & 2 & $\mathrm{~N}$ & $\mathrm{~A}$ & Graminoid & Poaceae \\
Panicum virgatum L. & 6 & $\mathrm{~N}$ & $\mathrm{P}$ & Graminoid & Poaceae \\
Parthenocissus Planch. & 4 & & & & Vitaceae \\
Parthenocissus quinquefolia (L.) Planch. & 4 & $\mathrm{~N}$ & $\mathrm{P}$ & Vine & Vitaceae \\
Paspalidium Stapf & 6 & & & & Poaceae \\
Paspalidium geminatum (Forsk.) Stapf & 6 & $\mathrm{~N}$ & $\mathrm{P}$ & Graminoid & Poaceae \\
Paspalum conjugatum Berg. & 4 & $\mathrm{~N}$ & $\mathrm{P}$ & Graminoid & Poaceae \\
Paspalum denticulatum Trin. & 4 & $\mathrm{~N}$ & $\mathrm{P}$ & Graminoid & Poaceae \\
Paspalum dissectum (L.) L. & 5 & $\mathrm{~N}$ & $\mathrm{P}$ & Graminoid & Poaceae \\
Paspalum distichum L. & 6 & $\mathrm{~N}$ & $\mathrm{P}$ & Graminoid & Poaceae \\
Paspalum floridanum Michx. & 4 & $\mathrm{~N}$ & $\mathrm{P}$ & Graminoid & Poaceae \\
Paspalum fluitans (Ell.) Kunth & 5 & $\mathrm{~N}$ & $\mathrm{~A}$ & Graminoid & Poaceae \\
Paspalum hydrophilum Henr. & 0 & $\mathrm{I}$ & $\mathrm{P}$ & Graminoid & Poaceae \\
Paspalum plicatulum Michx. & 4 & $\mathrm{~N}$ & $\mathrm{P}$ & Graminoid & Poaceae \\
Paspalum urvillei Steud. & 0 & $\mathrm{I}$ & $\mathrm{P}$ & Graminoid & Poaceae \\
Paspalum vaginatum Sw. & 7 & $\mathrm{~N}$ & $\mathrm{P}$ & Graminoid & Poaceae \\
Peltandra Raf. & 7 & & & Araceae \\
Peltandra virginica (L.) Schott & 7 & $\mathrm{~N}$ & $\mathrm{P}$ & Herb & Araceae
\end{tabular}




\section{Appendix Table. Plant species that occur in marshes and forested wetlands in coastal Louisiana.}

[CC, Cofficient of Conservatism score (0-10) assigned by the coastal Louisiana vegetation expert panel; $\mathrm{N}$, species that are native to the contiguous 48 States of the United States; I, species that are introduced; A, annual; P, perennial; B, biennial, following the U.S. Department of Agriculture's PLANTS Database (USDA, NRCS, 2008); †CC, score when the given species occurs in fresh and intermediate marshes; ¥CC, score when the given species occurs in brackish and saline marshes]

\begin{tabular}{|c|c|c|c|c|c|}
\hline Scientific name & CC & Origin & Duration & Form & Family \\
\hline Pennisetum L.C. Rich. ex Pers. & 0 & & & & Poaceae \\
\hline Pennisetum glaucum (L.) R. Br. & 0 & I & A & Graminoid & Poaceae \\
\hline Pentodon Hochst. & 2 & & & & Rubiaceae \\
\hline Pentodon pentandrus (K. Schum.) Vatke & 2 & $\mathrm{~N}$ & A & Herb & Rubiaceae \\
\hline Persea P. Mill. & 8 & & & & Lauraceae \\
\hline Persea borbonia (L.) Spreng. & 8 & $\mathrm{~N}$ & $\mathrm{P}$ & Tree & Lauraceae \\
\hline Persea palustris (Raf.) Sarg. & 8 & $\mathrm{~N}$ & $\mathrm{P}$ & Tree & Lauraceae \\
\hline Phanopyrum (Raf.) Nash & 8 & & & & Poaceae \\
\hline Phanopyrum gymnocarpon (Ell.) Nash & 8 & $\mathrm{~N}$ & $\mathrm{P}$ & Graminoid & Poaceae \\
\hline Phragmites Adans. & 6 & & & & Poaceae \\
\hline Phragmites australis (Cav.) Trin. ex Steud. & 6 & $\mathrm{~N}$ & $\mathrm{P}$ & Graminoid & Poaceae \\
\hline Phyla Lour. & 3 & & & & Verbenaceae \\
\hline Phyla fruticosa (Mill.) Kennedy & 0 & I & $\mathrm{P}$ & Herb & Verbenaceae \\
\hline Phyla lanceolata (Michx.) Greene & 3 & $\mathrm{~N}$ & $\mathrm{P}$ & Herb & Verbenaceae \\
\hline Phyla nodiflora (L.) Greene & 4 & $\mathrm{~N}$ & $\mathrm{P}$ & Herb & Verbenaceae \\
\hline Phytolacca L. & 1 & & & & Phytolaccaceae \\
\hline Phytolacca americana L. & 1 & $\mathrm{~N}$ & $\mathrm{P}$ & Herb & Phytolaccaceae \\
\hline Pilea Lindl. & 5 & & & & Urticaceae \\
\hline Pilea pumila (L.) Gray & 5 & $\mathrm{~N}$ & A & Herb & Urticaceae \\
\hline Pinus L. & 6 & & & & Pinaceae \\
\hline
\end{tabular}




\section{Appendix Table. Plant species that occur in marshes and forested wetlands in coastal Louisiana.}

[CC, Cofficient of Conservatism score (0-10) assigned by the coastal Louisiana vegetation expert panel; $\mathrm{N}$, species that are native to the contiguous 48 States of the United States; I, species that are introduced; A, annual; P, perennial; B, biennial, following the U.S. Department of Agriculture's PLANTS Database (USDA, NRCS, 2008); †CC, score when the given species occurs in fresh and intermediate marshes; ¥CC, score when the given species occurs in brackish and saline marshes]

\begin{tabular}{|c|c|c|c|c|c|}
\hline Scientific name & $\mathrm{CC}$ & Origin & Duration & Form & Family \\
\hline Pinus elliottii Engelm. & 6 & $\mathrm{~N}$ & $\mathrm{P}$ & Tree & Pinaceae \\
\hline Pinus taeda L. & 6 & $\mathrm{~N}$ & $\mathrm{P}$ & Tree & Pinaceae \\
\hline Planera J.F. Gmel. & 7 & & & & Ulmaceae \\
\hline Planera aquatica J.F. Gmel. & 7 & $\mathrm{~N}$ & $\mathrm{P}$ & Tree & Ulmaceae \\
\hline Platanthera L.C. Rich. & 5 & & & & Orchidaceae \\
\hline Platanthera lacera (Michx.) G. Don & 5 & $\mathrm{~N}$ & $\mathrm{P}$ & Herb & Orchidaceae \\
\hline Platanus L. & 6 & & & & Platanaceae \\
\hline Platanus occidentalis L. & 6 & $\mathrm{~N}$ & $\mathrm{P}$ & Tree & Platanaceae \\
\hline Pluchea Cass. & 2 & & & & Asteraceae \\
\hline Pluchea camphorata (L.) DC. & 2 & $\mathrm{~N}$ & A & Herb & Asteraceae \\
\hline Pluchea foetida (L.) DC. & 2 & $\mathrm{~N}$ & $\mathrm{P}$ & Herb & Asteraceae \\
\hline Pluchea odorata (L.) Cass. & 2 & $\mathrm{~N}$ & A & Herb & Asteraceae \\
\hline Polygala L. & 7 & & & & Polygalaceae \\
\hline Polygala incarnata L. & 8 & $\mathrm{~N}$ & A & Herb & Polygalaceae \\
\hline Polygala leptocaulis Torr. \& Gray & 7 & $\mathrm{~N}$ & A & Herb & Polygalaceae \\
\hline Polygala mariana P. Mill. & 7 & $\mathrm{~N}$ & A & Herb & Polygalaceae \\
\hline Polygonella Michx. & 4 & & & & Polygonaceae \\
\hline Polygonella polygama (Vent.) Engelm. \& Gray & 4 & $\mathrm{~N}$ & $\mathrm{P}$ & Subshrub & Polygonaceae \\
\hline Polygonum glabrum Willd. & 4 & $\mathrm{~N}$ & A & Herb & Polygonaceae \\
\hline Polygonum hydropiper L. & 0 & $\mathrm{I}$ & A & Herb & Polygonaceae \\
\hline
\end{tabular}




\section{Appendix Table. Plant species that occur in marshes and forested wetlands in coastal Louisiana.}

[CC, Cofficient of Conservatism score (0-10) assigned by the coastal Louisiana vegetation expert panel; $\mathrm{N}$, species that are native to the contiguous 48 States of the United States; I, species that are introduced; A, annual; P, perennial; B, biennial, following the U.S. Department of Agriculture's PLANTS Database (USDA, NRCS, 2008); †CC, score when the given species occurs in fresh and intermediate marshes; ¥CC, score when the given species occurs in brackish and saline marshes]

\begin{tabular}{|c|c|c|c|c|c|}
\hline Scientific name & C & Origin & Duration & Form & Family \\
\hline Polygonum hydropiperoides Michx. & 4 & $\mathrm{~N}$ & $\mathrm{P}$ & Herb & Polygonaceae \\
\hline Polygonum lapathifolium L. & 4 & $\mathrm{~N}$ & $\mathrm{~A}$ & Herb & Polygonaceae \\
\hline Polygonum pensylvanicum L. & 3 & $\mathrm{~N}$ & A & Herb & Polygonaceae \\
\hline Polygonum persicaria L. & 0 & I & A & Herb & Polygonaceae \\
\hline Polygonum punctatum Ell. & 5 & $\mathrm{~N}$ & A & Herb & Polygonaceae \\
\hline Polygonum sagittatum L. & 4 & $\mathrm{~N}$ & A & Vine & Polygonaceae \\
\hline Polygonum setaceum Baldw. & 4 & $\mathrm{~N}$ & $\mathrm{P}$ & Herb & Polygonaceae \\
\hline Polypogon interruptus Kunth & 7 & $\mathrm{~N}$ & $\mathrm{P}$ & Graminoid & Poaceae \\
\hline Polypogon monspeliensis (L.) Desf. & 0 & I & A & Graminoid & Poaceae \\
\hline Pontederia L. & 7 & & & & Pontederiaceae \\
\hline Pontederia cordata L. & 7 & $\mathrm{~N}$ & $\mathrm{P}$ & Herb & Pontederiaceae \\
\hline Populus L. & 5 & & & & Salicaceae \\
\hline Populus deltoides Bartr. ex Marsh. & 5 & $\mathrm{~N}$ & $\mathrm{P}$ & Tree & Salicaceae \\
\hline Portulaca oleracea L. & 0 & I & $\mathrm{A}$ & Herb & Portulacaceae \\
\hline Portulaca pilosa $\mathrm{L}$. & 5 & $\mathrm{~N}$ & $\mathrm{~A}$ & Herb & Portulacaceae \\
\hline Proserpinaca L. & 6 & & & & Haloragaceae \\
\hline Proserpinaca palustris L. & 6 & $\mathrm{~N}$ & $\mathrm{P}$ & Herb & Haloragaceae \\
\hline Ptilimnium Raf. & 4 & & & & Apiaceae \\
\hline Ptilimnium capillaceum (Michx.) Raf. & 4 & $\mathrm{~N}$ & $\mathrm{~A}$ & Herb & Apiaceae \\
\hline Quercus L. & 7 & & & & Fagaceae \\
\hline
\end{tabular}




\section{Appendix Table. Plant species that occur in marshes and forested wetlands in coastal Louisiana.}

[CC, Cofficient of Conservatism score (0-10) assigned by the coastal Louisiana vegetation expert panel; $\mathrm{N}$, species that are native to the contiguous 48 States of the United States; I, species that are introduced; A, annual; P, perennial; B, biennial, following the U.S. Department of Agriculture's PLANTS Database (USDA, NRCS, 2008); †CC, score when the given species occurs in fresh and intermediate marshes; ¥CC, score when the given species occurs in brackish and saline marshes]

\begin{tabular}{|c|c|c|c|c|c|}
\hline Scientific name & $\mathrm{CC}$ & Origin & Duration & Form & Family \\
\hline Quercus falcata Michx. & 6 & $\mathrm{~N}$ & $\mathrm{P}$ & Tree & Fagaceae \\
\hline Quercus laurifolia Michx. & 7 & $\mathrm{~N}$ & $\mathrm{P}$ & Tree & Fagaceae \\
\hline Quercus lyrata Walt. & 8 & $\mathrm{~N}$ & $\mathrm{P}$ & Tree & Fagaceae \\
\hline Quercus nigra L. & 7 & $\mathrm{~N}$ & $\mathrm{P}$ & Tree & Fagaceae \\
\hline Quercus phellos L. & 8 & $\mathrm{~N}$ & $\mathrm{P}$ & Tree & Fagaceae \\
\hline Quercus texana Buckl. & 7 & $\mathrm{~N}$ & $\mathrm{P}$ & Tree & Fagaceae \\
\hline Quercus virginiana P. Mill. & 5 & $\mathrm{~N}$ & $\mathrm{P}$ & Tree & Fagaceae \\
\hline Ranunculus L. & 1 & & & & Ranunculaceae \\
\hline Ranunculus muricatus L. & 0 & I & A & Herb & Ranunculaceae \\
\hline Ranunculus pusillus Poir. & 2 & $\mathrm{~N}$ & $\mathrm{~A}$ & Herb & Ranunculaceae \\
\hline Ranunculus sardous Crantz & 0 & I & $\mathrm{A}$ & Herb & Ranunculaceae \\
\hline Ranunculus sceleratus L. & 2 & $\mathrm{~N}$ & A & Herb & Ranunculaceae \\
\hline Ranunculus trilobus Desf. & 0 & I & $\mathrm{A}$ & Herb & Ranunculaceae \\
\hline Rayjacksonia R.L. Hartman \& M.A. Lane & 3 & & & & Asteraceae \\
\hline Rayjacksonia phyllocephala (DC.) R.L. Hartman \& M.L. Lane & 3 & $\mathrm{~N}$ & A & Herb & Asteraceae \\
\hline Rhexia L. & 7 & & & & Melastomataceae \\
\hline Rhexia mariana L. & 7 & $\mathrm{~N}$ & $\mathrm{P}$ & Herb & Melastomataceae \\
\hline Rhynchospora Vahl & 6 & & & & Cyperaceae \\
\hline Rhynchospora caduca Ell. & 7 & $\mathrm{~N}$ & $\mathrm{P}$ & Graminoid & Cyperaceae \\
\hline Rhynchospora capitellata (Michx.) Vahl & 5 & $\mathrm{~N}$ & $\mathrm{P}$ & Graminoid & Сyperaceae \\
\hline
\end{tabular}




\section{Appendix Table. Plant species that occur in marshes and forested wetlands in coastal Louisiana.}

[CC, Cofficient of Conservatism score (0-10) assigned by the coastal Louisiana vegetation expert panel; $\mathrm{N}$, species that are native to the contiguous 48 States of the United States; I, species that are introduced; A, annual; P, perennial; B, biennial, following the U.S. Department of Agriculture's PLANTS Database (USDA, NRCS, 2008); †CC, score when the given species occurs in fresh and intermediate marshes; ¥CC, score when the given species occurs in brackish and saline marshes]

\begin{tabular}{llllll}
\hline \multicolumn{1}{c}{ Scientific name } & C & Origin & Duration & Form & Family \\
\hline Rhynchospora cephalantha Gray & 5 & $\mathrm{~N}$ & $\mathrm{P}$ & Graminoid & Cyperaceae \\
Rhynchospora chalarocephala Fern. \& Gale & 6 & $\mathrm{~N}$ & $\mathrm{P}$ & Graminoid & Cyperaceae \\
Rhynchospora colorata (L.) H. Pfeiffer & 6 & $\mathrm{~N}$ & $\mathrm{P}$ & Graminoid & Cyperaceae \\
Rhynchospora corniculata (Lam.) Gray & 5 & $\mathrm{~N}$ & $\mathrm{P}$ & Graminoid & Cyperaceae \\
Rhynchospora globularis (Chapman) Small & 5 & $\mathrm{~N}$ & $\mathrm{~A}$ & Graminoid & Cyperaceae \\
Rhynchospora glomerata (L.) Vahl & 6 & $\mathrm{~N}$ & $\mathrm{P}$ & Graminoid & Cyperaceae \\
Rhynchospora inexpansa (Michx.) Vahl & 6 & $\mathrm{~N}$ & $\mathrm{P}$ & Graminoid & Cyperaceae \\
Rhynchospora macrostachya Torr. ex Gray & 7 & $\mathrm{~N}$ & $\mathrm{P}$ & Graminoid & Cyperaceae \\
Rhynchospora microcarpa Baldw. ex Gray & 7 & $\mathrm{~N}$ & $\mathrm{P}$ & Graminoid & Cyperaceae \\
Rhynchospora nitens (Vahl) Gray & 5 & $\mathrm{~N}$ & $\mathrm{~A}$ & Graminoid & Cyperaceae \\
Rorippa Scop. & 2 & & & & Brassicaceae \\
Rorippa palustris (L.) Bess. & 2 & $\mathrm{~N}$ & $\mathrm{~A}$ & Herb & Brassicaceae \\
Rorippa sessiliflora (Nutt.) A.S. Hitchc. & 2 & $\mathrm{~N}$ & $\mathrm{~A}$ & Herb & Brassicaceae \\
Rosa L. & 0 & & & Rosaceae \\
Rosa bracteata J.C. Wendl. & 0 & $\mathrm{I}$ & $\mathrm{P}$ & Vine & Rosaceae \\
Rotala indica (Willd.) Koehne & 0 & $\mathrm{I}$ & $\mathrm{A}$ & Herb & Lythraceae \\
Rotala ramosior (L.) Koehne & 4 & $\mathrm{~N}$ & $\mathrm{~A}$ & Herb & Lythraceae \\
Rubus L. & 4 & & & Posaceae \\
Rubus trivialis Michx. & 4 & $\mathrm{~N}$ & $\mathrm{P}$ & Subshrub \\
Ruellia L. & 0 & & & Rosaceae
\end{tabular}




\section{Appendix Table. Plant species that occur in marshes and forested wetlands in coastal Louisiana.}

[CC, Cofficient of Conservatism score (0-10) assigned by the coastal Louisiana vegetation expert panel; $\mathrm{N}$, species that are native to the contiguous 48 States of the United States; I, species that are introduced; A, annual; P, perennial; B, biennial, following the U.S. Department of Agriculture's PLANTS Database (USDA, NRCS, 2008); †CC, score when the given species occurs in fresh and intermediate marshes; ¥CC, score when the given species occurs in brackish and saline marshes]

\begin{tabular}{|c|c|c|c|c|c|}
\hline Scientific name & $\mathrm{CC}$ & Origin & Duration & Form & Family \\
\hline Ruellia caerulea Morong & 0 & I & $\mathrm{P}$ & Herb & Acanthaceae \\
\hline Rumex altissimus Wood & 3 & $\mathrm{~N}$ & $\mathrm{P}$ & Herb & Polygonaceae \\
\hline Rumex crispus L. & 0 & I & $\mathrm{P}$ & Herb & Polygonaceae \\
\hline Rumex verticillatus $\mathrm{L}$. & 3 & $\mathrm{~N}$ & $\mathrm{P}$ & Herb & Polygonaceae \\
\hline Sabal Adans. & 8 & & & & Arecaceae \\
\hline Sabal minor (Jacq.) Pers. & 8 & $\mathrm{~N}$ & $\mathrm{P}$ & Shrub & Arecaceae \\
\hline Sabal palmetto (Walt.) Lodd. ex J.A. \& J.H. Schultes & 8 & $\mathrm{~N}$ & $\mathrm{P}$ & Shrub & Arecaceae \\
\hline Sabatia Adans. & 6 & & & & Gentianaceae \\
\hline Sabatia angularis (L.) Pursh & 6 & $\mathrm{~N}$ & A & Herb & Gentianaceae \\
\hline Sabatia arenicola Greenm. & 6 & $\mathrm{~N}$ & A & Herb & Gentianaceae \\
\hline Sabatia calycina (Lam.) Heller & 6 & $\mathrm{~N}$ & $\mathrm{P}$ & Herb & Gentianaceae \\
\hline Sabatia campestris Nutt. & 5 & $\mathrm{~N}$ & A & Herb & Gentianaceae \\
\hline Sabatia stellaris Pursh & 6 & $\mathrm{~N}$ & A & Herb & Gentianaceae \\
\hline Saccharum L. & 3 & & & & Poaceae \\
\hline Saccharum giganteum (Walt.) Pers. & 3 & $\mathrm{~N}$ & $\mathrm{P}$ & Graminoid & Poaceae \\
\hline Sacciolepis Nash & 6 & & & & Poaceae \\
\hline Sacciolepis striata (L.) Nash & 6 & $\mathrm{~N}$ & $\mathrm{P}$ & Graminoid & Poaceae \\
\hline Sagittaria australis (J.G. Sm.) Small & 5 & $\mathrm{~N}$ & $\mathrm{P}$ & Herb & Alismataceae \\
\hline Sagittaria graminea Michx. & 5 & $\mathrm{~N}$ & $\mathrm{P}$ & Herb & Alismataceae \\
\hline Sagittaria guayanensis Kunth & 0 & I & $\mathrm{P}$ & Herb & Alismataceae \\
\hline
\end{tabular}




\section{Appendix Table. Plant species that occur in marshes and forested wetlands in coastal Louisiana.}

[CC, Cofficient of Conservatism score (0-10) assigned by the coastal Louisiana vegetation expert panel; $\mathrm{N}$, species that are native to the contiguous 48 States of the United States; I, species that are introduced; A, annual; P, perennial; B, biennial, following the U.S. Department of Agriculture's PLANTS Database (USDA, NRCS, 2008); †CC, score when the given species occurs in fresh and intermediate marshes; ¥CC, score when the given species occurs in brackish and saline marshes]

\begin{tabular}{|c|c|c|c|c|c|}
\hline Scientific name & CC & Origin & Duration & Form & Family \\
\hline Sagittaria lancifolia L. & 6 & $\mathrm{~N}$ & $\mathrm{P}$ & Herb & Alismataceae \\
\hline Sagittaria latifolia Willd. & 5 & $\mathrm{~N}$ & $\mathrm{P}$ & Herb & Alismataceae \\
\hline Sagittaria papillosa Buch. & 5 & $\mathrm{~N}$ & $\mathrm{P}$ & Herb & Alismataceae \\
\hline Sagittaria platyphylla (Engelm.) J.G. Sm. & 5 & $\mathrm{~N}$ & $\mathrm{P}$ & Herb & Alismataceae \\
\hline Salicornia L. & 6 & & & & Chenopodiaceae \\
\hline Salicornia bigelovii Torr. & 5 & $\mathrm{~N}$ & A & Herb & Chenopodiaceae \\
\hline Salicornia depressa Standl. & 7 & $\mathrm{~N}$ & $\mathrm{P}$ & Herb & Chenopodiaceae \\
\hline Salix caroliniana Michx. & 5 & $\mathrm{~N}$ & $\mathrm{P}$ & Tree & Salicaceae \\
\hline Salix nigra Marsh. & 2 & $\mathrm{~N}$ & $\mathrm{P}$ & Tree & Salicaceae \\
\hline Sambucus L. & 2 & & & & Caprifoliaceae \\
\hline Sambucus nigra L. & 2 & $\mathrm{~N}$ & $\mathrm{P}$ & Shrub & Caprifoliaceae \\
\hline Samolus L. & 6 & & & & Primulaceae \\
\hline Samolus valerandi L. & 6 & $\mathrm{~N}$ & $\mathrm{P}$ & Herb & Primulaceae \\
\hline Saururus L. & 7 & & & & Saururaceae \\
\hline Saururus cernuus L. & 7 & $\mathrm{~N}$ & $\mathrm{P}$ & Herb & Saururaceae \\
\hline Schoenoplectus (Reichenb.) Palla & 7 & & & & Cyperaceae \\
\hline Schoenoplectus americanus (Pers.) Volk. ex Schinz \& R. Keller & 8 & $\mathrm{~N}$ & $\mathrm{P}$ & Graminoid & Cyperaceae \\
\hline Schoenoplectus californicus (C.A. Mey.) Palla & 7 & $\mathrm{~N}$ & $\mathrm{P}$ & Graminoid & Cyperaceae \\
\hline Schoenoplectus deltarum (Schuyler) Sojak & 8 & $\mathrm{~N}$ & $\mathrm{P}$ & Graminoid & Cyperaceae \\
\hline Schoenoplectus maritimus (L.) Lye & 7 & $\mathrm{~N}$ & $\mathrm{P}$ & Graminoid & Сyperaceae \\
\hline
\end{tabular}




\section{Appendix Table. Plant species that occur in marshes and forested wetlands in coastal Louisiana.}

[CC, Cofficient of Conservatism score (0-10) assigned by the coastal Louisiana vegetation expert panel; $\mathrm{N}$, species that are native to the contiguous 48 States of the United States; I, species that are introduced; A, annual; P, perennial; B, biennial, following the U.S. Department of Agriculture's PLANTS Database (USDA, NRCS, 2008); †CC, score when the given species occurs in fresh and intermediate marshes; ¥CC, score when the given species occurs in brackish and saline marshes]

\begin{tabular}{llllll}
\hline \multicolumn{1}{c}{ Scientific name } & CC & Origin & Duration & Form & Family \\
\hline Schoenoplectus pungens (Vahl) Palla & 7 & $\mathrm{~N}$ & $\mathrm{P}$ & Graminoid & Cyperaceae \\
Schoenoplectus robustus (Pursh) M.T. Strong & 7 & $\mathrm{~N}$ & $\mathrm{P}$ & Graminoid & Cyperaceae \\
Schoenoplectus tabernaemontani (K.C. Gmel.) Palla & 7 & $\mathrm{~N}$ & $\mathrm{P}$ & Graminoid & Cyperaceae \\
Scirpus L. & 6 & & & & Cyperaceae \\
Scirpus cyperinus (L.) Kunth & 5 & $\mathrm{~N}$ & $\mathrm{P}$ & Graminoid & Cyperaceae \\
Scirpus lineatus Michx. & 6 & $\mathrm{~N}$ & $\mathrm{P}$ & Graminoid & Cyperaceae \\
Scutellaria L. & 5 & & & & Lamiaceae \\
Scutellaria lateriflora L. & 5 & $\mathrm{~N}$ & $\mathrm{P}$ & Herb & Lamiaceae \\
Scutellaria ovata Hill & 5 & $\mathrm{~N}$ & $\mathrm{P}$ & Herb & Lamiaceae \\
Senna P. Mill. & 4 & & & & Fabaceae \\
Senna obtusifolia (L.) Irwin \& Barneby & 4 & $\mathrm{~N}$ & $\mathrm{~A}, \mathrm{P}$ & Herb & Fabaceae \\
Sesbania Scop. & 1 & & & & Fabaceae \\
Sesbania drummondii (Rydb.) Cory & 2 & $\mathrm{~N}$ & $\mathrm{P}$ & Shrub & Fabaceae \\
Sesbania herbacea (P. Mill.) McVaugh & 2 & $\mathrm{~N}$ & $\mathrm{~A}$ & Shrub & Fabaceae \\
Sesbania punicea (Cav.) Benth. & 0 & $\mathrm{I}$ & $\mathrm{P}$ & Subshrub & Fabaceae \\
Sesbania vesicaria (Jacq.) Elliot & 2 & $\mathrm{~N}$ & $\mathrm{~A}$ & Subshrub & Fabaceae \\
Sesuvium L. & 4 & & & Aizoaceae \\
Sesuvium maritimum (Walt.) B.S.P. & 4 & $\mathrm{~N}$ & $\mathrm{~A}$ & Herb & Aizoaceae \\
Sesuvium portulacastrum (L.) L. & 5 & $\mathrm{~N}$ & $\mathrm{P}$ & Herb & Aizoaceae \\
Setaria faberi Herm. & 0 & $\mathrm{I}$ & $\mathrm{A}$ & Graminoid & Poaceae
\end{tabular}




\section{Appendix Table. Plant species that occur in marshes and forested wetlands in coastal Louisiana.}

[CC, Cofficient of Conservatism score (0-10) assigned by the coastal Louisiana vegetation expert panel; $\mathrm{N}$, species that are native to the contiguous 48 States of the United States; I, species that are introduced; A, annual; P, perennial; B, biennial, following the U.S. Department of Agriculture's PLANTS Database (USDA, NRCS, 2008); †CC, score when the given species occurs in fresh and intermediate marshes; ¥CC, score when the given species occurs in brackish and saline marshes]

\begin{tabular}{|c|c|c|c|c|c|}
\hline Scientific name & CC & Origin & Duration & Form & Family \\
\hline Setaria italica (L.) Beauv. & 0 & I & A & Graminoid & Poaceae \\
\hline Setaria magna Griseb. & 4 & $\mathrm{~N}$ & A & Graminoid & Poaceae \\
\hline Setaria parviflora (Poir.) Kerguelen & 3 & $\mathrm{~N}$ & $\mathrm{P}$ & Graminoid & Poaceae \\
\hline Setaria pumila (Poir.) Roemer \& J.A. Schultes & 0 & I & A & Graminoid & Poaceae \\
\hline Setaria verticillata (L.) Beauv. & 0 & I & A & Graminoid & Poaceae \\
\hline Smilax L. & 5 & & & & Smilacaceae \\
\hline Smilax bona-nox L. & 5 & $\mathrm{~N}$ & $\mathrm{P}$ & Vine & Smilacaceae \\
\hline Smilax laurifolia L. & 5 & $\mathrm{~N}$ & $\mathrm{P}$ & Vine & Smilacaceae \\
\hline Smilax rotundifolia L. & 5 & $\mathrm{~N}$ & $\mathrm{P}$ & Vine & Smilacaceae \\
\hline Solanum L. & 3 & & & & Solanaceae \\
\hline Solanum ptycanthum Dunal & 3 & $\mathrm{~N}$ & $\mathrm{~A}$ & Herb & Solanaceae \\
\hline Solidago L. & 4 & & & & Asteraceae \\
\hline Solidago fistulosa P. Mill. & 4 & $\mathrm{~N}$ & $\mathrm{P}$ & Herb & Asteraceae \\
\hline Solidago sempervirens L. & 4 & $\mathrm{~N}$ & $\mathrm{P}$ & Herb & Asteraceae \\
\hline Solidago stricta Ait. & 4 & $\mathrm{~N}$ & $\mathrm{P}$ & Herb & Asteraceae \\
\hline Sonchus L. & 0 & & & & Asteraceae \\
\hline Sonchus asper (L.) Hill & 0 & I & A & Herb & Asteraceae \\
\hline Sonchus oleraceus L. & 0 & I & $\mathrm{A}$ & Herb & Asteraceae \\
\hline Sorghum Moench & 0 & & & & Poaceae \\
\hline Sorghum halepense (L.) Pers. & 0 & I & $\mathrm{P}$ & Graminoid & Poaceae \\
\hline
\end{tabular}




\section{Appendix Table. Plant species that occur in marshes and forested wetlands in coastal Louisiana.}

[CC, Cofficient of Conservatism score (0-10) assigned by the coastal Louisiana vegetation expert panel; $\mathrm{N}$, species that are native to the contiguous 48 States of the United States; I, species that are introduced; A, annual; P, perennial; B, biennial, following the U.S. Department of Agriculture's PLANTS Database (USDA, NRCS, 2008); †CC, score when the given species occurs in fresh and intermediate marshes; ¥CC, score when the given species occurs in brackish and saline marshes]

\begin{tabular}{lccccc}
\hline \multicolumn{1}{c}{ Scientific name } & CC & Origin & Duration & Form & Family \\
\hline Sparganium L. & 7 & & & & Sparganiaceae \\
Sparganium americanum Nutt. & 7 & $\mathrm{~N}$ & $\mathrm{P}$ & Graminoid & Sparganiaceae \\
Spartina alterniflora Loisel. & 10 & $\mathrm{~N}$ & $\mathrm{P}$ & Graminoid & Poaceae \\
Spartina cynosuroides (L.) Roth & 8 & $\mathrm{~N}$ & $\mathrm{P}$ & Graminoid & Poaceae \\
Spartina patens (Ait.) Muhl. & 9 & $\mathrm{~N}$ & $\mathrm{P}$ & Graminoid & Poaceae \\
Spartina pectinata Bosc ex Link & 4 & $\mathrm{~N}$ & $\mathrm{P}$ & Graminoid & Poaceae \\
Spartina spartinae (Trin.) Merr. ex A.S. Hitchc. & 8 & $\mathrm{~N}$ & $\mathrm{P}$ & Graminoid & Poaceae \\
Spergularia (Pers.) J.\& K. Presl & 6 & & & & Caryophyllaceae \\
Spergularia salina J.\& K. Presl & 6 & $\mathrm{~N}$ & $\mathrm{~A}$ & Herb & Caryophyllaceae \\
Spermacoce L. & 4 & & & & Rubiaceae \\
Spermacoce glabra Michx. & 4 & $\mathrm{~N}$ & $\mathrm{P}$ & Herb & Rubiaceae \\
Sphenoclea Gaertn. & 0 & & & & Sphenocleaceae \\
Sphenoclea zeylanica Gaertn. & 0 & $\mathrm{I}$ & $\mathrm{A}$ & Herb & Sphenocleaceae \\
Spiranthes L.C. Rich. & 8 & & & & Orchidaceae \\
Spiranthes odorata (Nutt.) Lindl. & 8 & $\mathrm{~N}$ & $\mathrm{P}$ & Herb & Orchidaceae \\
Sporobolus R. Br. & 9 & & & Poaceae \\
Sporobolus virginicus (L.) Kunth & 9 & $\mathrm{~N}$ & $\mathrm{P}$ & Graminoid & Poaceae \\
Stachys L. & 4 & & & Lamiaceae \\
Stachys tenuifolia Willd. & 4 & $\mathrm{~N}$ & $\mathrm{P}$ & Herb & Lamiaceae \\
Steinchisma Raf. & 4 & & & & Poaceae
\end{tabular}




\section{Appendix Table. Plant species that occur in marshes and forested wetlands in coastal Louisiana.}

[CC, Cofficient of Conservatism score (0-10) assigned by the coastal Louisiana vegetation expert panel; $\mathrm{N}$, species that are native to the contiguous 48 States of the United States; I, species that are introduced; A, annual; P, perennial; B, biennial, following the U.S. Department of Agriculture's PLANTS Database (USDA, NRCS, 2008); †CC, score when the given species occurs in fresh and intermediate marshes; ¥CC, score when the given species occurs in brackish and saline marshes]

\begin{tabular}{|c|c|c|c|c|c|}
\hline Scientific name & CC & Origin & Duration & Form & Family \\
\hline Steinchisma hians (Ell.) Nash & 4 & $\mathrm{~N}$ & $\mathrm{P}$ & Graminoid & Poaceae \\
\hline Strophostyles Ell. & 6 & & & & Fabaceae \\
\hline Strophostyles helvola (L.) Elliott & 6 & $\mathrm{~N}$ & A & Vine & Fabaceae \\
\hline Strophostyles umbellata (Muhl. ex Willd.) Britt. & 7 & $\mathrm{~N}$ & $\mathrm{P}$ & Vine & Fabaceae \\
\hline Styrax L. & 7 & & & & Styracaceae \\
\hline Styrax americanus Lam. & 7 & $\mathrm{~N}$ & $\mathrm{P}$ & Shrub & Styracaceae \\
\hline Suaeda Forsk. ex J.F. Gmel. & 5 & & & & Chenopodiaceae \\
\hline Suaeda linearis (Ell.) Moq. & 5 & $\mathrm{~N}$ & A & Herb & Chenopodiaceae \\
\hline Symphyotrichum Nees & 4 & & & & Asteraceae \\
\hline Symphyotrichum dumosum (L.) Nesom & 4 & $\mathrm{~N}$ & $\mathrm{P}$ & Herb & Asteraceae \\
\hline Symphyotrichum elliotii (Torr. \& Gray) Nesom & 4 & $\mathrm{~N}$ & $\mathrm{P}$ & Herb & Asteraceae \\
\hline Symphyotrichum subulatum (Michx.) Nesom & 4 & $\mathrm{~N}$ & A & Herb & Asteraceae \\
\hline Symphyotrichum tenuifolium (L.) Nesom & 5 & $\mathrm{~N}$ & $\mathrm{P}$ & Herb & Asteraceae \\
\hline Symphyotrichum turbinellum (Lindl.) Nesom & 4 & $\mathrm{~N}$ & $\mathrm{P}$ & Herb & Asteraceae \\
\hline Tamarix L. & 0 & & & & Tamaricaceae \\
\hline Tamarix africana Poir. & 0 & I & $\mathrm{P}$ & Shrub & Tamaricaceae \\
\hline Tamarix canariensis Willd. & 0 & I & $\mathrm{P}$ & Shrub & Tamaricaceae \\
\hline Tamarix gallica $\mathrm{L}$. & 0 & I & $\mathrm{P}$ & Shrub & Tamaricaceae \\
\hline Taxodium L.C. Rich. & 10 & & & & Cupressaceae \\
\hline Taxodium distichum (L.) L.C. Rich. & 10 & $\mathrm{~N}$ & $\mathrm{P}$ & Tree & Cupressaceae \\
\hline
\end{tabular}




\section{Appendix Table. Plant species that occur in marshes and forested wetlands in coastal Louisiana.}

[CC, Cofficient of Conservatism score (0-10) assigned by the coastal Louisiana vegetation expert panel; $\mathrm{N}$, species that are native to the contiguous 48 States of the United States; I, species that are introduced; A, annual; P, perennial; B, biennial, following the U.S. Department of Agriculture's PLANTS Database (USDA, NRCS, 2008); †CC, score when the given species occurs in fresh and intermediate marshes; ¥CC, score when the given species occurs in brackish and saline marshes]

\begin{tabular}{|c|c|c|c|c|c|}
\hline Scientific name & C & Origin & Duration & Form & Family \\
\hline Teucrium L. & 5 & & & & Lamiaceae \\
\hline Teucrium canadense $\mathrm{L}$. & 5 & $\mathrm{~N}$ & $\mathrm{P}$ & Herb & Lamiaceae \\
\hline Thalia L. & 5 & & & & Marantaceae \\
\hline Thalia dealbata Fraser ex Roscoe & 5 & $\mathrm{~N}$ & $\mathrm{P}$ & Herb & Marantaceae \\
\hline Thelypteris Schmidel & 7 & & & & Thelypteridaceae \\
\hline Thelypteris palustris Schott & 7 & $\mathrm{~N}$ & $\mathrm{P}$ & Fern & Thelypteridaceae \\
\hline Toxicodendron P. Mill. & 2 & & & & Anacardiaceae \\
\hline Toxicodendron radicans (L.) Kuntze & 2 & $\mathrm{~N}$ & $\mathrm{P}$ & Vine & Anacardiaceae \\
\hline Triadenum Raf. & 7 & & & & Clusiaceae \\
\hline Triadenum virginicum (L.) Raf. & 7 & $\mathrm{~N}$ & $\mathrm{P}$ & Herb & Clusiaceae \\
\hline Triadenum walteri (J.G. Gmel.) Gleason & 6 & $\mathrm{~N}$ & $\mathrm{P}$ & Herb & Clusiaceae \\
\hline Triadica Loureiro & 0 & & & & Euphorbiaceae \\
\hline Triadica sebifera (L.) Small & 0 & I & $\mathrm{P}$ & Tree & Euphorbiaceae \\
\hline Triglochin L. & 8 & & & & Juncaginaceae \\
\hline Triglochin striata Ruiz \& Pav. & 8 & $\mathrm{~N}$ & $\mathrm{P}$ & Graminoid & Juncaginaceae \\
\hline Tripsacum L. & 5 & & & & Poaceae \\
\hline Tripsacum dactyloides (L.) L. & 5 & $\mathrm{~N}$ & $\mathrm{P}$ & Graminoid & Poaceae \\
\hline Typha L. & 2 & & & & Typhaceae \\
\hline Typha angustifolia L. & 0 & I & $\mathrm{P}$ & Graminoid & Typhaceae \\
\hline Typha domingensis Pers. & 3 & $\mathrm{~N}$ & $\mathrm{P}$ & Graminoid & Typhaceae \\
\hline
\end{tabular}




\section{Appendix Table. Plant species that occur in marshes and forested wetlands in coastal Louisiana.}

[CC, Cofficient of Conservatism score (0-10) assigned by the coastal Louisiana vegetation expert panel; $\mathrm{N}$, species that are native to the contiguous 48 States of the United States; I, species that are introduced; A, annual; P, perennial; B, biennial, following the U.S. Department of Agriculture's PLANTS Database (USDA, NRCS, 2008); †CC, score when the given species occurs in fresh and intermediate marshes; ¥CC, score when the given species occurs in brackish and saline marshes]

\begin{tabular}{|c|c|c|c|c|c|}
\hline Scientific name & $\mathrm{CC}$ & Origin & Duration & Form & Family \\
\hline Typha latifolia L. & 2 & $\mathrm{~N}$ & $\mathrm{P}$ & Graminoid & Typhaceae \\
\hline Ulmus L. & 7 & & & & Ulmaceae \\
\hline Ulmus alata Michx. & 6 & $\mathrm{~N}$ & $\mathrm{P}$ & Tree & Ulmaceae \\
\hline Ulmus americana L. & 8 & $\mathrm{~N}$ & $\mathrm{P}$ & Tree & Ulmaceae \\
\hline Ulmus rubra Muhl. & 6 & $\mathrm{~N}$ & $\mathrm{P}$ & Tree & Ulmaceae \\
\hline Uniola L. & 9 & & & & Poaceae \\
\hline Uniola paniculata $\mathrm{L}$. & 9 & $\mathrm{~N}$ & $\mathrm{P}$ & Graminoid & Poaceae \\
\hline Verbena L. & 2 & & & & Verbenaceae \\
\hline Verbena hastata L. & 3 & $\mathrm{~N}$ & $\mathrm{P}$ & Herb & Verbenaceae \\
\hline Verbena litoralis Kunth & 0 & I & $\mathrm{P}$ & Herb & Verbenaceae \\
\hline Verbena scabra Vahl & 3 & $\mathrm{~N}$ & $\mathrm{~A}$ & Herb & Verbenaceae \\
\hline Verbena urticifolia L. & 3 & $\mathrm{~N}$ & $\mathrm{P}$ & Herb & Verbenaceae \\
\hline Veronica L. & 2 & & & & Scrophulariaceae \\
\hline Veronica peregrina L. & 2 & $\mathrm{~N}$ & A & Herb & Scrophulariaceae \\
\hline Vicia L. & 0 & & & & Fabaceae \\
\hline Vicia lutea $\mathrm{L}$. & 0 & I & A & Vine & Fabaceae \\
\hline Vigna Savi & 3 & & & & Fabaceae \\
\hline Vigna luteola (Jacq.) Benth. & 3 & $\mathrm{~N}$ & $\mathrm{P}$ & Vine & Fabaceae \\
\hline Vitis L. & 5 & & & & Vitaceae \\
\hline Vitis rotundifolia Michx. & 5 & $\mathrm{~N}$ & $\mathrm{P}$ & Vine & Vitaceae \\
\hline
\end{tabular}




\section{Appendix Table. Plant species that occur in marshes and forested wetlands in coastal Louisiana.}

[CC, Cofficient of Conservatism score (0-10) assigned by the coastal Louisiana vegetation expert panel; $\mathrm{N}$, species that are native to the contiguous 48 States of the United States; I, species that are introduced; A, annual; P, perennial; B, biennial, following the U.S. Department of Agriculture's PLANTS Database (USDA, NRCS, 2008); †CC, score when the given species occurs in fresh and intermediate marshes; ¥CC, score when the given species occurs in brackish and saline marshes]

\begin{tabular}{lccccc}
\hline \multicolumn{1}{c}{ Scientific name } & CC & Origin & Duration & Form & Family \\
\hline Woodwardia Sm. & 7 & & & & Blechnaceae \\
Woodwardia areolata (L.) T. Moore & 7 & $\mathrm{~N}$ & $\mathrm{P}$ & Fern & Blechnaceae \\
Woodwardia virginica (L.) Sm. & 7 & $\mathrm{~N}$ & $\mathrm{P}$ & Fern & Blechnaceae \\
Xyris L. & 7 & & & & Xyridaceae \\
Xyris caroliniana Walt. & 6 & $\mathrm{~N}$ & $\mathrm{P}$ & Herb & Xyridaceae \\
Xyris laxifolia Mart. & 7 & $\mathrm{~N}$ & $\mathrm{P}$ & Graminoid & Xyridaceae \\
Zanthoxylum L. & 7 & & & & Rutaceae \\
Zanthoxylum clava-herculis L. & 7 & $\mathrm{~N}$ & $\mathrm{P}$ & Tree & Rutaceae \\
Zizania L. & 6 & & & & Poaceae \\
Zizania aquatica L. & 6 & $\mathrm{~N}$ & $\mathrm{P}$ & Graminoid & Poaceae \\
Zizaniopsis Doell \& Aschers. & 5 & & & & Poaceae \\
Zizaniopsis miliacea (Michx.) Doell \& Aschers. & 5 & $\mathrm{~N}$ & $\mathrm{P}$ & Graminoid & Poaceae \\
\hline
\end{tabular}

